\title{
A Comparative-Qualitative Research Analysis of Character Education in the Christian School and Home Education Milieu
}

Gretchen M. Wilhelm

Cedarville University

Follow this and additional works at: http://digitalcommons.cedarville.edu/education theses

Part of the Education Commons

\section{Recommended Citation}

Wilhelm, Gretchen M., "A Comparative-Qualitative Research Analysis of Character Education in the Christian School and Home Education Milieu" (2005). Master of Education Research Theses. 12.

http://digitalcommons.cedarville.edu/education_theses/12 


\title{
A COMPARATIVE-QUALITATIVE RESEARCH \\ ANALYSIS OF CHARACTER EDUCATION IN THE \\ CHRISTIAN SCHOOL AND HOME EDUCATION MILIEU
}

\author{
A thesis submitted in partial fulfillment \\ of the requirements for the degree of \\ Masters of Education
}

By

\section{GRETCHEN MARIE WILHELM}

B.M. Music History and Literature, Baldwin-Wallace Conservatory of Music, 2002

2005

Cedarville University 


\section{CEDARVILLE UNIVERSITY}

\section{SCHOOL OF GRADUATE STUDIES}

May 7, 2005

I HEREBY RECOMMEND THAT THE THESIS PREPARED UNDER MY SUPERVISION BY Gretchen Marie Wilhelm ENTITLED A Comparative-Qualitative Research Analysis of Character Education in the Christian School and Home Education Milieu BE ACCEPTED IN PARTIAL FULFILLMENT OF THE REQUIREMENTS FOR THE DEGREE OF Master of Education.

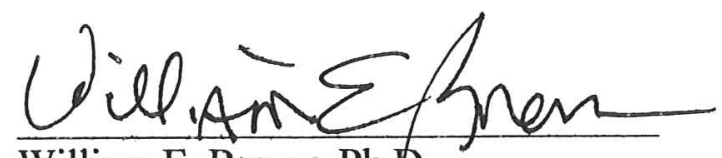

William E. Brown, Ph.D.

Cedarville University President

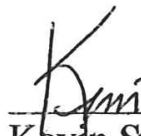

Kevin Sims, Ph.D.

Dean, School of Social Sciences and Professional Studies

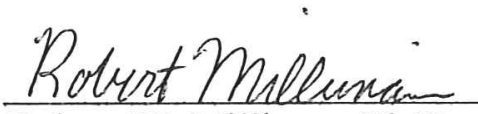

Robert W. Milliman, Ph.D. Academic Vice President

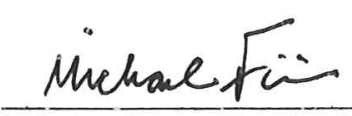

Michael W. Firmin, Ph.D.

Psychology Department Chairman

Thesis Advisor 


\begin{abstract}
Wilhelm, Gretchen Marie. M. Ed. Education Dept., Cedarville University, 2005. A Comparative-Qualitative Research Analysis of Character Education in the Christian School and Home Education Milieu.
\end{abstract}

This qualitative study provides a phenomenological perspective and comparative analysis of character education within the Christian school and home education milieu. The study is based on semi-structured interviews of fifty-two individuals $(\mathrm{N}=52)$ representative of a sampling of Christian educators from four private, evangelical Christian Schools $(n=26)$ and area home educating families $(n=26)$. The intent of the researcher was to bring attention to the importance for Christian educators to come to terms with the worldview from which the desire to educate Christian youth in a separate moral community originates. Although the purpose and intent of both sets of educators were in many instances similar, significant deviations in methodology and application were found. The results of this study are defined in four similarities and six differences, suggesting that character education and the juxtaposition of that goal along with the transference of faith was a major contributor to the obvious commitment and calling felt by Christian educators. 


\section{TABLE OF CONTENTS}

CHAPTER I: Introduction..........................................................................

Educational Significance................................................1

Purpose of the Study..................................................

Review of Literature.................................................4

Research Methodology.................................................9

Biblical Integration...................................................11

Application...........................................................14

Summary.......................................................14

CHAPTER II: Review of Literature ..............................................16

Importance of the Issue................................................16

Defining the Terms..................................................... 19

Philosophy of Character Education.....................................22

Significant Factors...............................................29

Evaluation of Character Education Models...................................31

Historical Perspectives.................................................34

Christian School Movement Today.......................................39

Home Education Movement Today.......................................40

Contemporary Research...............................................42

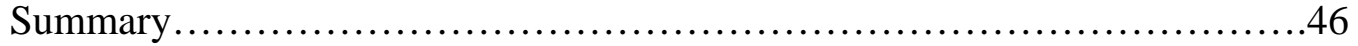


CHAPTER III: Research Method....................................................48

Project Development.....................................................48

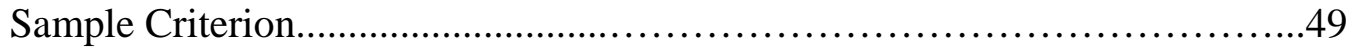

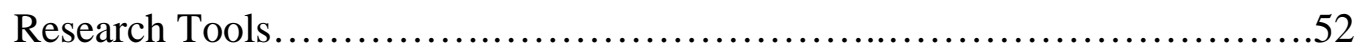

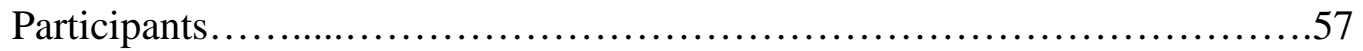

Descriptive Statistics....................................................60

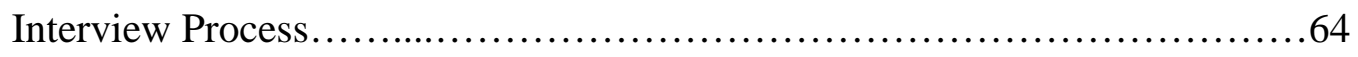

Cataloging Interviewee Responses.......................................65

Qualitative Coding of the Data...........................................66

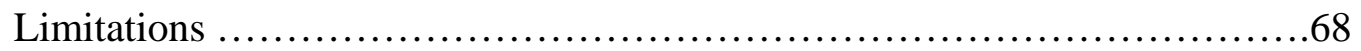

CHAPTER IV: Qualitative Findings............................................. 70

Profound Commitment.................................................... 70

Importance of Character Education......................................73

Character Education Defined by Milieu...................................75

Foundational Philosophy .................................................

Significance of Educational Structure in Character Development...............82

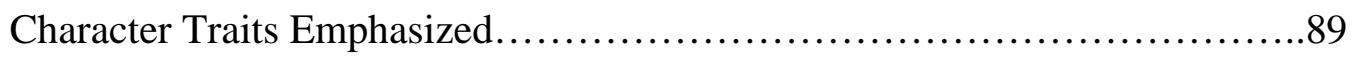

Models Implemented in Christian School...................................................91

Models Implemented in Home Education.......................................95

Evaluation of Character Education........................................99

Perspective Outcomes of Character Education...............................102

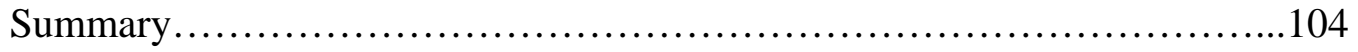




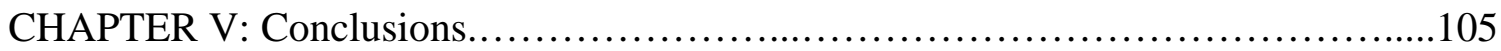

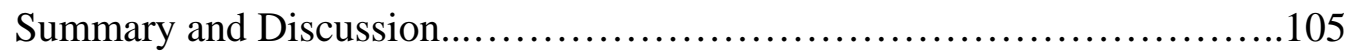

Suggestions for Implementation.................................... 107

Recommendations for Future Research..................................109

APPENDICES ..................................................................... 112

APPENDIX A: Sample Selection Criterion Checklist.........................112

APPENDIX B: Subject Interview Release Form .........................113

APPENDIX C: Subject Profile Form and Field Notes........................114

APPENDIX D: Christian School Semi-Structured Interview Tool.............116

APPENDIX E: Home Education Semi-Structured Interview Tool..............118

APPENDIX F: Project Explanation/ Formal Request for Participation..........120

APPENDIX I: Sample of Parent Survey...............................121

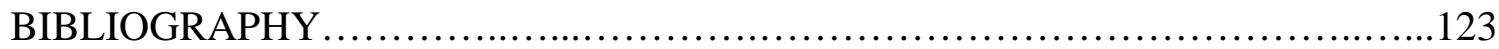

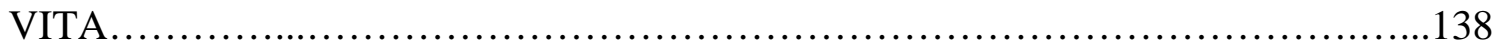




\section{LIST OF TABLES}

Table 1: Profile Correlation Table of Christian Schools Comprising Interviewee Places of Employment $(n=4)$. .51

Table 2: Sample Profile of Years of Teaching Experience of Christian Educator

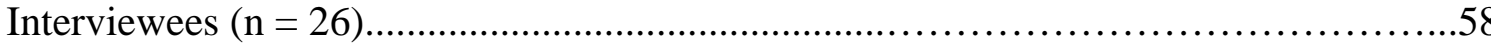

Table 3: Sample Profile of Years of Teaching Experience of Home Educating

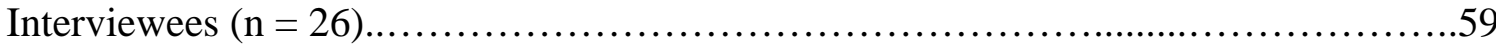

Table 4: Comparative Sample Profile of Interviewee’s Level of Educational

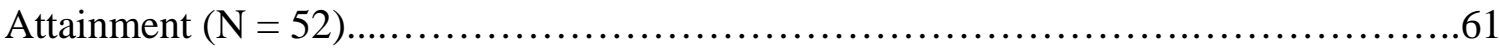

Table 5: Scatter Plot of Number of Children in the Home Educating Households of

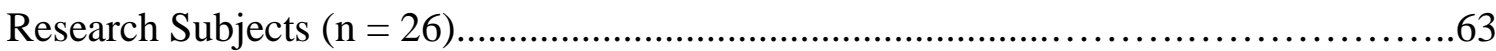




\section{ACKNOWLEDGEMENTS}

This work is dedicated to my Lord and Savior Jesus Christ, the God and Father of Abraham, Isaac, and Jacob who has had His hand upon me from my mother's womb and who has so lovingly directed my steps to this point. This is my prayer, that I would be filled with the knowledge of His will in all wisdom and spiritual understanding; so that I may have a walk worthy of the Lord, fully pleasing Him in every way, being fruitful in every good work and increasing in the knowledge of God; strengthened with all might according to His glorious power, giving thanks to the Father who has qualified me to be a partaker of the inheritance of the saints in the kingdom of light. For He has rescued me from darkness and brought me near into the kingdom of the Son He loves, in whom I have redemption, the forgiveness of sin.

Colossians 1:9-14

To Dr. Stephen Gruber, thank you for guiding me through the Cedarville Graduate Program. I am grateful for your encouragement to attend the Focus on the Family Institute during the course of my graduate work. Your wise counsel and cheerful assistance were invaluable to me.

To my students and fellow teachers at Greater Cleveland Christian High School, thank you for the many experiences you provided to me in my first year of teaching. As Music Director, I enjoyed all of you electric guitar players! As the $7^{\text {th }} \& 9^{\text {th }}$ grade health teacher, I was tremendously blessed to challenge you to remain pure and keep yourself emotionally and physically as a keepsake for your future spouse.

To the amazing staff and mentors at Focus on the Family Institute. My life was impacted by your ministry and training. The Lord, in His perfect timing, led me to spend those months in Colorado to grow me up in my faith while He faithfully provided for my every need. Thank you for all the time and effort you put forth to invest in the future leaders of this nation. Thanks to all the remarkable people I rubbed shoulders with while attending, you are all so special. Carpe Diem!

To all 'my kids,' the $6^{\text {th }}$ grade students at Christian Community School, I have enjoyed your fun and creative potential. You are so special to me. Go for God and live for Him always! To the wonderful CCS staff - Many thanks for encouraging me, through your example, to see teaching as a precious ministry opportunity. I am so grateful that God has placed me to serve in your midst.

Finally, to my future husband, this degree is only one of the things that the Lord has called me to complete as I wait in eager anticipation of the day when I will pledge my life to you before God. I pray that God is preparing you to be the man of God that He desires you to be and will give you great courage and strength to make an impact for His kingdom. 


\section{DEDICATION}

I want to dedicate this thesis to my great-grandmother, Marie Teresa Smith, my grandmother, Marilyn Marie Mulligan, and to my mother, Sue Marie Wilhelm, all of whom have passed down to me, through the generations, an incredible legacy of teaching.

Having been given the middle name of Marie, I am proud to continue this heritage. Thank you for your inspiration and encouragement to enter into the challenging field of education. Grandma Mulligan - your faithful service to the Lord through your numerous teaching capacities over the years has been such a monument to God's grace working in and through you. Mom - you are a spectacular home educator, a treasured example of a godly woman, a loving and sincere mentor, a trustworthy confidant, and truly my best friend. Your enthusiastic love for learning and your desire to continually pour into your children has made all the difference in my life. Thank you for my thirteen years of home education and for allowing us all to share so many rich learning experiences together as a

family. Thank you most of all mom and dad for filling me with a burning passion for the Lord and His will for my life. 


\section{CHAPTER I: Introduction}

American society and its public educational institutions continue to display a denunciation of Christian influence, the advancement of humanistic ideology, a crisis of character, and moral laxity. This endemic awareness has fueled a revival of character education and has also served as a catalyst in the outgrowth of Christian schools and more recently the home education movement. The support for these educational options, which provide opportunity for spiritual formation and character development as a foundation for knowledge, stands as a testimony to the desire of parents and educators to influence student integrity. The recognition that moral development and spiritual formation is a necessary component in the acquisition of knowledge appears to be a major contributor to those who choose options other than the public schools for the academic development of their youth.

\section{Educational Significance}

The face of American education in the $21^{\text {st }}$ century has experienced rapid transformation brought about by many contributing factors. Most disturbing among these are the humanistic secularization of public education and the internal purging of the Judeo-Christian foundation of morality and societal ethics. It is therefore significant to note the unique sociological phenomenon existing in response to this rejection of the religious underpinnings of American public education. The continual growth of private schools and the increasing rate of home education (Ray, 1999; US Department of Education, 2001) indicate a movement away from public education, especially within the evangelical Christian community. 
Some concerned parents have bailed out of public schools, choosing rather to fund a private education for their children. Others accept the full responsibility of that education and seek to provide a learning lifestyle for their children in the form of home education. One prominent author noted, "homeschooling's most important lesson is that parental involvement is essential to a child's academic success” (Dobson, 2003, p. 204). Current trends reveal that a number of Christian parents feel they can no longer entrust the public school system with their child's potential, let alone their safety and academic advancement (National Home Education Research Institute, 2000).

The alternative to public education must be a clear and distinctive differentiation from a secular education. Christian virtue and moral development are, at times, assumed rather than purposefully implemented in Christian schools. In the home education milieu, the opportunity for parents to develop their child's character abound, if they recognize it as the foundational motive for that form of education. Consequently, both venues should remember that, "while criteria for effective character education program development and implementation can be found in the literature, many character education programs fail to be grounded in a well-researched conceptual framework” (Leming, 2000).

Character development is imperative as a central tenant of a Christian student's educational attainment. Therefore, it is important for Christian educators to come to terms with the worldview from which the desire to educate Christian youth in a separate moral community originates. Coons (1992) stated: "Raising our children to represent our own values is the most important form of speech most of us will ever experience...For most parents, it is obvious that their chance to influence the world abides largely in the 
message they are able to embody in their descendants” (Coons, 1992, p. 16). For this reason it is necessary to examine the models utilized in character development within the Christian school and home education milieu in order to better serve the purpose for which Christian education was first conceptualized. Thus, analysis of this issue is vital as it goes beyond the individual success to impact future families, communities, governments, and consequently society at large.

\section{Purpose of the Study}

The primary purpose of this comparative-qualitative research analysis is to reveal common patterns or themes regarding character education and to heuristically further research in this area. As such, this study will add to the body of knowledge available to education professionals as a median to the cultural climate of Christian education in both the traditional form and home education. Organizations such as Association of Christian Schools International (ASCI), American Association of Christian Schools (AACS), and others will benefit from the information gathered in this study. The intent of the researcher is to provide information, in the form of qualitative data, regarding current practices and the epistemological understanding of character education in the Christian school and home education arena. Thus, the study's first goal is to generate hypotheses created from grounded theory that will promote further research in this area.

A second function of this study is to shed light on the current expansion of home education in evangelical Christian circles and its relationship to formal Christian education. For Christian educators, the importance of this study has far reaching ramifications. It probes potential motivations and the rationales of home education, 
offering insight concerning common misconceptions as to the roles and motives of parents who home educate. In addition, an aspect of the study adds to the body of documented knowledge of home education compared to Christian education generally and also particularly as applied to character education. It is the researcher's desire that Christian educators become more aware of their counterparts in the home education community in order that mutual support and collaboration might more often take place.

Finally, this study is purposed to inspire a re-evaluation of the foundational motivations of Christian education, namely character development and spiritual formation. The researcher anticipates uncovering salient information and offering practical models for success in the area of character education. In this manner, the study aspires to facilitate a return to the essence of Christian education and to justify a reassessment of current practice within the local Christian school or home education model.

\section{Review of Literature}

The Greek philosopher Plutarch (circa 45 - 125 A.D.) wrote, "The very spring and root of honesty and virtue lie in a good education” (in Brooks, 2001, p. 72). Character formation and the moral development of students have become a central issue in American education and school reform initiatives in recent years. Character development is acknowledged by most educators as an important context in which to promote cooperation and learning. Dawidowicz (2003) observes that "teaching morality has become prevalent in not just parochial and private schools, but also public schools throughout the United States” (p. 276). 
Hunter (2003) believes that the most effective context for the teaching of morality is within a unified community. He states: "There is a body of evidence that shows moral education has its most enduring effects on young people when they inhabit a social world that coherently incarnates a moral culture defined by a clear and intelligible understanding of public and private good” (p. 154). This unique social culture within a Christian community or within a family unit is a necessary part of creating an environment conducive to the development of character. Therefore one must consider that "the formation of character in students requires a coherent moral culture that includes a shared understanding of the goals of education and a shared narrative that is linked to a socially embodied tradition” (Glanzer, 2003, p.302). The uniqueness of the Christian school and home education milieu is that it does indeed provide this type of cohesive environment which can effectively promote the amalgamation of character and virtue.

The historical Christian underpinnings and social context for Biblical morality serve as an active part in early American education. The morality traditionally taught was based solely upon one primary authority: "The Bible served as the primary textbook for reading and the daily lessons reinforced a commitment to moral codes of behavior based upon the Scripture” (Algera \& Sink, 2002, p. 163). American society provided a moral basis on which to relate relevant scruples, yet this is no longer true. During the 1960s and 1970s, more didactic forms of character education stemming from the early $20^{\text {th }}$ century surrendered to "the new values clarification approach" (Raths, Hermin, \& Simon, 1966). This new approach gave no basis for absolute truth and instead allowed for, and actually encouraged, alternate realities (Kirschenbaum, 1977). Valuesclarification was intended as an intervention to alleviate the values confusion of students 
by teaching these individuals to apply a process of valuing so as to diminish comparison between absolutes.

Increased secularization of American society and the causal effects this has on education enables theorists now to recognize this dilemma. The importance of the understanding of the Christian Worldview in regards to all aspects of life and learning is essential in the shaping of our views of education and thus the development of character in Christian students leading to moral astuteness.

Morality is bound up with our place in a community or tradition, our understanding of nature and human nature, our convictions about the afterlife, our experiences of the sacred; our assumptions about what the mind can know, and our understanding of what makes like meaningful. We make sense of what we ought to do, of what kind of person we should be, in light of all these aspects of life - at least if we are reflective (Nord \& Haynes, 1998, p. 185).

During the 1980s and 1990s, educators who viewed the values clarification approach as morally relativistic and ultimately detrimental to the goal of character development, began advocating a return to character education (Lickona, 1991; Ryan, 1986; Wynne, 1991). Still, confusion as to what constitutes this new secular morality significantly increased the difficulty in the unification of the movement. Alexander (2003) accurately expressed this secularization of moral virtue: "It does not follow that to be ethical or moral one must believe in God. But it does imply that one must believe that something is of value beyond one's self and one's community....To think of the absence of the sacred that is, its total absence, is to conceive a condition in which nothing excites horror. And in such a world, moral education cannot gain a foothold” (p. 366). 
The fundamental nature of the unique social culture, or peer group, created in Christian education and the home education milieu is a significant contributor to the success of character formation. Christian educators and parents have come to understand that, "teaching character is a holistic enterprise" (Davis, 2003, p. 48) and those who have recognized this now realize, “character education cannot be isolated, codified, and packaged into tidy little instructional units in a how-to manual” (Gilness, 2003, p. 243). Christian educators and parents have sought to provide a discipleship-based model in nurturing the educational advancement of their children with the expectation that by surrounding them with godly role-models and consistent instruction in righteousness they will safeguard their spiritual, social, and physical development.

The discipleship-based model provides for complete integration of Christian Worldview and Biblical thinking to enable the student to approach life foundationally secure and to address the challenges they encounter. The home education milieu, even more so than the Christian school environment, intrinsically lends itself to this model:

The point is that we must have a system of education which is intensely personal and relationship driven so that virtue is added to faith, and knowledge to virtue, as required by Scripture; a system that trains the believer to "think God's thoughts after him" through a pre-suppositionally biblical approach to truth; a system which rejects the idea that either our methods or our philosophy of education are neutral; and a system which emphasizes that the supreme goal of education is not simply to fill the mind with facts, or to get a credential, but to see the child transformed after the image of the God who made him (Phillips, 2003, p. 124).

This view of Christian education is in direct contrast to many secular educational theorists. William Bennett, a well known proponent of character education, argues that the significant question for educationalists is not what values should be promoted in schools, but exactly how that transmission of moral authority is to take place (Bennett, 
1992). Moral authority, when conveyed through personal, committed relationships is most effectively accomplished through a discipleship-based model.

The development of Christian educational alternatives, at its foundation, not only expresses moral and educational values, but is also ideological - a desire to create a common moral ethos and educational environment for Christian students. Molnar (1997) clearly expresses the incompatibility of the bipolar secular position on this issue: "I believe that if the virtues of humility, faith, self-denial, and charity are to have any functional utility in secular educational institutions, and in a democratic society, then they have to be 'decoupled' from their religious roots and secularized” (p.166).

A successful Christian character education program involves, "grounding in actual moral conditions rather than simply a consideration of abstract moral principles or developmental standards” (Crawford, 2001, p. 126). In order for character and virtue to be established in the lives of Christian students there must be present the environment and opportunity for those valued character qualities to be practiced. As Glanzer (2003) states: "This commonality [provided in Christian education] creates a base of moral authority that joins students, parents, and faculty in a sense of common mission and purpose” (p. 302). The comprehensive nature of biblical character integration is the central facet of a strong Christian educational experience. This concept of active learning in the retention of moral standards is further explored by Algera \& Sink (2002) who state: "A comprehensive approach to character and moral education should focus on the influence of the learning community and provide opportunities for students to become actively engaged in character formation” (p. 178). 


\section{Research Methodology}

The research method in this study will examine and compare the application of character education in the Christian school and home education milieu. The study will take the form of a phenomenological-qualitative research analysis. This particular research approach is based on the qualitative inquiry model which is characterized by its search for understanding of social phenomenon (Sowell, 2001). This research describes and explains a pattern of relationships, which can be accomplished within a set of conceptually specified categories (Mishler, 1990). Thus, a phenomenological-qualitative research methodology allows for observation and in-depth interviews to generate patterns of continuity and contrast that will ultimately embody the research constructs the researcher will analyze. This method of constant comparison, originally advocated by Glaser and Strauss (1967), will influence the analysis of the interview data collected for this study.

Consistent with internal validity protocol for qualitative research, a criterionbased method of sample selection will be implemented (see Appendix A) in order to obtain subjects who: 1) are professing evangelical Christians, 2) have taught for a minimum of five years, 3) are currently active in either Christian education or home education, and 4) reside in a specified geographical region of northeastern Ohio. These subjects $(\mathrm{N}=52)$, are representative of regional evangelical Christian educators and home educating parents who will sign a release form (see Appendix B) before being interviewed. Moreover, a detailed profile (see Appendix C) of each interviewee will be recorded by the researcher with a numbered code assigned to each as a tracking 
mechanism. Characteristics of the interview participants are summarized in Table 1-5 (see Chapter III).

The researcher will conduct interviews with selected representatives from four area Christian schools and a selection of home education parents from northern Ohio. These individuals will comprise the research sample for this study and will include administrators, teachers, and parents. The interview sessions will be conducted in a semistructured format, approximately 20 to 40 minutes in duration, and will be audio-taped for later transcription. A series of eight interview questions were prepared for this study in consultation with the research advisor. Two corresponding versions of this research tool were developed so as to direct the questions meaningfully to the individuals from the Christian school or home education respectively (see Appendix D \& E).

The researcher will perform two rounds of interviewing in this qualitative study. The first round of interviews will include the total number of sample subjects $(\mathrm{N}=52)$. A second round of repeat interviews from both groups will then take place with particular individuals believed to be key informants in order to clarify and expand upon previous data gathered. A third round of interviews may be conducted as the final stage of the interview process. This possible final set of interviews may be structured as a group interview with a diminutive number of representatives from each group. This group interview is purposed to address specific issues that have emerged as a result of previously gathered data. Throughout the entire interviewing process, the researcher will document running commentary and field notes, that later will aid in the coding of the data and the generating of potential hypothesis. 
After all interviews have been completed by the researcher, they will then be transcribed and the results analyzed to determine patterns of response. An inductive process of coding will be used, deriving categories and themes from the data itself (Weber, 1990). This inductive approach to data analysis is expected to result in the emergence of a number of broad themes or grounded theory. A thematic categorization will be utilized to identify the central themes from the first round of interviews and this information will then be tested and revised through analyses of succeeding interviews.

\section{Biblical Integration}

Numerous individuals in the Scriptures are commended for their character. In the lineage of the tribe of Benjamin, as listed in the book of 1 Samuel, Aphiah was set apart from the rest of his family with this approbation: “a Benjaminite of stalwart character" (I Samuel 9: 1-2, NASB). The sons of Asher are described as "responsible, excellent in character, and brave in battle, fit for leadership" (1 Chronicles 7: 40, NIV). Job is commended of the Lord for being a man who was "blameless and upright in character" (Job 1: 1, NIV). Ruth is recognized as a woman of "noble character" (Ruth 3:10-11, NIV). Zechariah and Elizabeth are both described as "upright in the sight of God, observing all the Lord's commandments and regulations blamelessly” (Luke 1:5-6, NIV). Joseph of Arimathea is described as "a man of good heart and character” (Luke 23:50, MSG). These individuals, and many others, are highly regarded because of their godly character and noble actions; these are the heroes of old. 
In the book of Proverbs, virtue is upheld and noble character is declared to be "worth far more than fine rubies" (Proverbs 31: 10, NIV). Cultivating the character of Christ should be the unvarying goal of the life of the follower of Christ and it is for this reason Paul admonishes the Christians in Rome not to let sin reign in their lives (Romans 6: 12-14, NIV). Paul describes "proven character" (Philippians 2: 21-23, NIV) and the necessary progressive development of such character: "tribulation brings about perseverance; and perseverance, proven character; and proven character, hope; and this hope does not disappoint, because the love of God has been poured out within our hearts through the Holy Spirit who was given to us” (Romans 5: 3-5, NASB).

The Biblical account of the fall of man, as recorded in Genesis chapter three, explains that the desire for good is often superseded by mankind's sinful and depraved nature. It is, consequently, a struggle to cultivate a life of character. This is evident in the classroom since it is never necessary to educate a child to do the wrong thing but, on the contrary, inspiring the pursuit of that which is right and true is often a battle. The unwieldy sin nature struggles against one's desire for what is good and according to the Scriptures, this struggle is a spiritual reality (Romans 7: 19-21). The Bible states that mankind's fallen, sinful state dictates natural human desire, especially in ones youth (Proverbs 22:15). Therefore, it is necessary to systematically cultivate character and virtue and to continually train children in it (Luke 6: 40, NIV).

The primary responsibility for molding and shaping a child's character is firmly established in the divinely ordained institution of the family (Deuteronomy 4, 11:18-21; Proverbs 22:6). According to the Bible, children belong to God, but the responsibility 
and authority to raise and educate them is delegated to parents: "Lo, children are a heritage of the Lord: and the fruit of the womb is his reward” (Psalm 127:3, KJV). In Genesis 33:5, Jacob introduces his children to his brother Esau as "the children which God hath graciously given your servant." For those parents who make the decision to educate their children in a Christian environment, that decision is often based upon an epistemological desire to train and educate their children in accordance with the Biblical mandate. Paul admonished Timothy to "keep a firm grasp on both your character and your teaching. Don't be diverted” (1 Timothy 4:16, MSG). The call to cultivate character and virtue among students should remain a vital and firmly established component in the framework of Christian education which is based on God's Word, the love of Christ, and the guidance of the Holy Spirit.

The Scriptures teach that fathers are to instruct their children and continuously remind them of the attributes and commands of God (Deuteronomy 11:18-21). A fourfold list of the goals of education, from God's perspective, are found in the Psalms: to train children in God's laws so they can govern themselves; be wiser than their enemies; have more insight than their teachers; and understand more than the aged (Psalm 119:97101, NIV). The book of Proverbs says, "The integrity of the honest keeps them on track; Moral character makes for smooth traveling, but an evil life is a hard life. Good character is the best insurance; crooks get trapped in their sinful lust” (Proverbs 11:3, 5-6a, NIV). The apostle Paul declared, "Beware lest any man spoil you [or your children] through philosophy and vain deceit, after the tradition of men, after the rudiments of the world, and not after Christ" (Colossians 2:8, NIV). He warned the early Christians, "Be not deceived: evil communications corrupt good manners" (1 Corinthians 15:33, NIV). 
Christian parents are, and should be, all the more concerned with the education of their children since it is clear that God has entrusted them to "produce a godly offspring" (Malachi 2:15, NIV) and to bring up this godly seed "in the nurture and admonition of the Lord” (Ephesians 6:4, KJV).

\section{Application}

The projected practical application of this comparative-qualitative research analysis will be applied within the investigator's own domain. A re-evaluation of the various character development programs of Christian Community School in Eaton, Ohio will be a natural result of the research process of this study. The various methods currently implemented, specifically in the $6^{\text {th }}$ grade, to cultivate and produce character within Christian Community School's student population will be critiqued and analyzed in relation to the outcomes of this study. Through this process, a reassessment of the researcher's own understanding of character education and classroom teaching objectives in view of character training and spiritual formation will be formulated.

\section{Summary}

The qualitative research method employed in this study examines and compares the application of character education in the Christian school and home education milieu will occur via phenomenological research analysis. The research question addressed in this study will be principally of educational significance in the evangelical Christian community. Yet, since the importance of character education is recognized even within the secular realm as an essential component to education, this study also will be beneficial to others who wish to gain insight into Christian school and home education 
models of character development. The success of Christian schools and home education to produce affirmative outcomes in character development and academic growth among its students will be examined. The outcome of this study, therefore, is primarily purposed to reveal current trends and to facilitate a greater understanding of the phenomena of character education within the multiplicity of Christian schools and home education models. 


\section{CHAPTER II: Review of Literature}

The theory and practice of character education in the public schools experienced a revival in the 1990s (Lickona, 1993) and has received a lot of attention in the past decade as educational specialists sought for a means to address the escalating violence and behavioral concerns facing public school educators. Lickona (1993) believes that “character education is making a comeback in American schools” (p. 6). Ferguson (1999) suggests that "across the country, schools... are turning to programs of character education in hopes of inoculating kids with the values of civility and integrity, against the depredations of a popular culture that often seems to reward neither” (p. 68). One cynic expressed this renewed interest when he sarcastically alleged, "Character education seems to have replaced apple pie and motherhood as the best example of that which no one should object” (Davis, 2003, p.32).

\section{Importance of the Issue}

The lack of character and moral instruction in the secular arena has accentuated the importance of character education in recent years. In removing all forms of religious expression and definition of moral virtue, American public schools have now recognized what is best expressed in the sentiment, "In addition to the fact that Johnny still can't read, we are now faced with the more serious problem that he can't tell right from wrong”. (Kilpatrick, 1992, p. 87). The need to address character issues, as specifically related to behavioral concerns, is underscored by Wynne (1992) who said, “Schools are and must be concerned about pupils' morality. Any institution with the 
custody of children or adolescents for long periods of time, such as a school, inevitably affects the character of its charges” (p. 151).

William Bennett (1991), a prominent public figure and proponent of character education, wrote honestly: "If we want our children to possess the traits of character we most admire, we need to teach them what those traits are” (p. 133). The intentional instruction of character within the education process is, in fact, the essence of true education. It was Theodore Roosevelt who once said, “To educate a person in mind and not in morals is to educate a menace to society” (in Noll, 2003, p. 94). This argument can be taken to its logical conclusion: "They [the proponents of Character Education] seek to transform the beliefs and behavior of a generation not merely because they think it is desirable, but because they hold that the health of democracy depends upon their success” (Revell, 2002, p. 430). Therefore, the significance of examining character education and the methodology with which it is implemented is a valuable and necessary exercise for contemporary educators.

John Dewey (1964), as part of his pedagogical creed, asserted: “Every teacher should realize the dignity of his calling; that he is a social servant set apart for the maintenance of proper social order and the securing of the right social growth”. (p. 439) Since the Judeo-Christian ethic and standard for character is being expelled from the public schools, one must grapple with the reality that the American society is in danger of moral decline and the abandonment of traditionally held values. Dwight D. Eisenhower said, "Without a moral and spiritual awakening there is no hope for us.” One of our founding fathers, Samuel Adams, declared, "I thank God that I have lived to see my 
country independent and free. She may enjoy her independence and freedom if she will. It will depend on her virtue.” Even Benjamin Franklin wrote, “Only virtuous people are capable of freedom.” If this is true, then the issue of character and moral development of the next generation of American society is of the utmost importance. Indeed, it is a central issue in the advancement of education in America.

The educational objective of good citizenship and moral development has been largely abandoned in place of the multiplicity of multiculturalism and the callous defense of anti-establishment. O’ Sullivan (2004) stresses the importance of character education as the bedrock of democracy. He reflects that, "Democracy was considered unworkable without an educated and morally responsible populace” (p. 16). This sentiment is echoed by Wagner (2002) who said, “Democracy is not a values-free form of government” (p. 54). The recognition of the necessity of a moral populace for democracy to function is a sobering reminder of the importance of character education. He goes on to conclude, "local communities, rather than state, must decide what is most important to learn in regards to values” (Wagner, 2002, p. 54). To dismiss the importance of character development and abandon the purposeful instruction of character and traditional ethic is to abandon the American Republic our founding fathers handed down to us (Kilpatrick, 1992; Molnar, 1997).

Character development is imperative as a central tenant of a Christian student's educational attainment. Therefore, it is important for Christian educators to come to terms with the worldview from which the desire to educate Christian youth in a separate moral community originates. (p.16) stated: "Raising our children to represent our own 
values is the most important form of speech most of us will ever experience...For most parents, it is obvious that their chance to influence the world abides largely in the message they are able to embody in their descendants” (p. 16). Thus, analysis of this issue is vital as it goes well beyond the individual success to impact future families, communities, governments, and consequently society at large.

\section{Defining the Terms}

The word character comes from a Greek word, which means to engrave. O’Sullivan (2004) therefore defines character in this way: "Literally, then, character traits are those markings engraved upon us that lead us to behave in specific ways” (p. 98). These impressed values are those that have been reinforced, imprinted, and upheld in the education and experience of the individual. Bulach (2002) defined character as, “An intrinsic attitude or belief that determines a person's behavior in relation to other people and in relation to one's self” (p. 79). Another author phrased it this way, "At its root, character education is defined as moral excellence and firmness. Integrity refers to soundness or a firm adherence to a code of moral values” (Anderson, 2000, p.141). Thus, according to these authors, character can be measured corresponding to the individual's observance of a behavioral standard or the individual's compliance to a set moral code.

Most individuals would align themselves with the definition given by Murphy (1998): “Character education means coming to understand, care about, and practice virtue” (p. 159). Lickona (1991) echoes this logic when he offers this very concise definition of character: "Good character consists of knowing the good, desiring the good, 
and doing the good” (p. 51). The idea of knowing this good must stem from the understanding of the ideological motivation and parameters of moral conscience within the constraints of a specific values system. Within this in view, Guinness (1999) points out the exclusivity of a person’s character, "Distinct from such concepts as personality, image, reputation, or celebrity, it is the essential 'stuff' a person is made of, the inner reality and quality in which thoughts, speech, decisions, behavior, and relations are rooted." This author then goes on to state that character, "Lies deeper than values and far deeper than philosophies, allegiances, memberships, or accomplishments” (p. 12).

Developing in students a desire for the good is the ideal in character development. In this way, students come to a place in which they choose to pursue the good character rather then the alternative as a matter of preference. This moral authority is aptly described by Crawford (2001): "Substantive moral qualities are the primary locus for moral authority with respect to personal conduct and should always be present as part of a person's natural endowment and upbringing” (p. 125). The ideal of moral authority, that a student would choose the good because of preference and conscience, is based on an understanding of human nature. Most authors in the literature would consider the child as a "clean slate" (Glanzer, 2003). This basic conviction is an indicator of the understanding of the basic goodness of humanity and of the moral purity of the young. Although the Biblical understanding of the fallen state of man interferes with this line of thought, the recognition that a child is more capable of adopting moral standards early in life is universally recognized. 
Davis (2003) describes this seemingly natural moral tendency as, “A relatively settled general disposition of a person to do what is morally good” (p. 33). In this way, the development of character in students is not necessarily based upon rules and regulations, but rather it is the development of personal convictions and values. This "natural moral tendency" also assumes a philosophical standard of right and wrong. Lickona (1997) further states, "Character Education is the deliberate, pro-active effort to develop good character in kids. Or more simply: to teach children right from wrong. It assumes that right and wrong do exist; that there is objective, moral standards that transcend time, culture, and individual choice” (p. 131). Some utopian expectations also exist as to what this moral tendency produces. Cornett \& Chant (2000) extol a lofty sense of the term character: "Connectedness and mutual obligation to each other, and to reach beyond ourselves to higher aspirations, reflecting nobler impulses” (p. 29).

Comparison between the long-term goals of character education should also be examined relative to the need of character. The importance of creating a life-long natural moral tendency is described by one author who states, "Any attempt a school makes to improve a student's character, that is, to make more likely than otherwise that the student will do what he/she should do - not simply today, but for many years to come is essential for society” (Davis, 2003, p. 34). It is agreed that a successful character education program must therefore include "grounding in actual moral conditions rather than a consideration of abstract moral principles or developmental standards” (Crawford, 2001, p. 126). 
Finally, character is most often defined and evaluated based upon behavioral objectives. Wynne \& Ryan (1993) recognized this valuation commonality within the educational community: "Character centers on conduct, it focuses on the regular display of desirable traits in pupils” (p. 57). Authors repeatedly have affirmed the need to integrate character education, not because of religious affiliation or ideological motivation, but in order to address behavioral problems throughout the school day and as an attempt to influence the students against the poor choices exhibited by their peer groups (Anderson, 2000; Guinness, 1999; O’Sullivan, 2004). Therefore, in view of the literature, Milson \& Mehlig (2002) present a seemingly fitting definition, stateing: "Character Education is commonly defined as the process of developing in students an understanding of, commitment to, and tendency to behave in accordance with core ethical values” (p. 47).

\section{Philosophy of Character Education}

The philosophy of character education has traditionally been dependent upon the Biblical standard on which the Judeo-Christian system of ethics is founded. The importance of the understanding of this Christian worldview in regards to all aspects of life and learning is essential in the shaping of the educational worldview from which the programs purposed for the development of character in Christian schools are constructed. Thus, even the secular philosophy of character education and the understanding of morality are strongly tied to Christianity's doctrine of the nature of man and the nature of God. 
Those recognizing a moral standard apart from the knowledge of God would err in their attempts to interpose a moral standard apart from that of the divine. This basic proponent of the understanding of moral reasoning is expressed by one author:

Morality is bound up with our place in a community or tradition, our understanding of nature and human nature, our convictions about the afterlife, our experiences of the sacred; our assumptions about what the mind can know, and our understanding of what makes like meaningful. We make sense of what we ought to do, of what kind of person we should be, in light of all these aspects of life - at least if we are reflective (Nord \& Haynes, 1998, p. 185).

The absence of such a central belief as a divine law makes the attempt of moral development and character education a pitiable objective for those who reject the Biblical standard for ethics. If Christianity is not the approach from which character and moral living is based, what then is the standard? This quandary is echoed by those theorists who lament the fact that the theoretical basis for the current secular character education movement is somewhat loosely defined and subjective in its approach. Schultz (2001) expressed this philosophical dilemma in this way: "The character education faction is eclectic, lacking a core theoretical perspective and common practice” (p. 4).

Kagan (2001), when commenting on the view of character education in today's society, stated: "The need for character education is clear, the support for character education is almost universal” (p. 52). Individuals might disagree as to what system of virtues should be taught. They may even vehemently dispute as to whether or not it is possible to teach those virtues in such a way as to render them untouched by religion, but overall most educators recognize the crisis of moral illiteracy that pervades today's educational communities. Benninga (1988) suggests that the ongoing debate about how to teach morals, ethics, and good character in the schools really comes down to a 
competition between the product desired and the process by which that product is to be achieved.

The general public is to some extent in agreement about what constitutes good character. In fact, numerous published lists of character traits and virtues are remarkably similar in content. C. S. Lewis (1947), in an attempted to support the Biblical framework for character in a multicultural way, researched the ancient Egyptians, Babylonians, Hebrews, Chinese, Indians, and Greeks was well as Anglo Saxon and American cultures and writings. What he found were common values including kindness, honesty, justice, mercy, courage, loyalty to parents, spouses and family members, an obligation to help the poor, the sick, and the less fortunate, and the right to private property. Lewis (1947) called this commonality of morality within these great civilizations "the universal path to becoming a good person” (p. 83). Yet, this multicultural attempt to show a relationship within the development of time-honored codes of morality simply reflects those JudeoChristian ethics from which they are derived.

After the philosophic basis of morality within the Christian framework is understood and recognized, the question then becomes: Is the teaching of morality and character something that just happens in the course of a Christian education? Many would say this assumption is presumptuous. Character education must be purposefully crafted in order to be meaningful and effective, although Williams (2003) naively suggests:

Character education may thus emerge naturally from guided interactions among students, and between each student and a caring, conscientious teacher, while discussing, exploring, and mastering academic subjects” (p. 24). 
Lickona \& Lewis (1997) advocates: "The question is not whether to do character education or to do character development, but whether we do it carefully or whether we just do it inadvertently” (p. 27). Character education must be anchored in sound beliefs system of virtue: "When moral educators merely teach a common political-morality (e.g. civic virtues, etc.) that fails to be both comprehensive and socially rooted, character education ceases to be effective” (Glanzer, 2003, p. 301).

Character education must also reflect the moral culture from which it has emerged. Glanzer (2003) says: “The formation of character in students requires a coherent moral culture that includes a shared understanding of the goals of education and a shared narrative that is linked to a socially embodied tradition” (p. 302). Thus, no two character education programs should look exactly the alike. Each reflects the uniqueness of the community it serves. A proper character education program must also provide a safe, engaging learning environment, according to Algera \& Sink (2002) who assert: "A comprehensive approach to character and moral education should focus on the influence of the learning community and provide opportunities for students to become actively engaged in their own character formation” (p. 178).

Other authors and theorists bemoan the relativistic and lethargic way in which right and wrong are presented to students. Alexander (2003) declares, "In recent years, parents and teachers have too often become inarticulate and insecure about what to say to children concerning how best to live their lives” (p. 367). This backlash of post modernism asserts that Christian virtue and absolute truth cannot be held as exclusive 
morality. Educators are sometimes tormented with the irrational fear that they need to be very careful never to push on their students any form of morality or absolutes, but to create an environment in which they can determine their own set of moral truths. This epidemic of fear is described plainly by one source: "For several decades now educators have been fearful about indoctrinating students rather than educating them” (Ryan \& Bohlin, 1999, p. 15).

Another important aspect of the philosophy of character education that is vital to the success of any such program is identifying and supporting teachers who are able to model ethical behavior with creativity and caring (Anderson, 2000; Lickona, 1991; Weber 1998). This has proved to be another great difficulty faced by the public sector when attempting to implement character education. The obvious lack of moral role models and familial support in many students’ life is a giant hurdle to overcome. The literature would agree that in order for students to attain moral astuteness they must have it modeled and thereby reproduced in the process of learning. Anderson (2000) illustrates this point: “Our students must be surrounded in the education environment with professional educators who emulate character traits such as integrity, courage, trustworthiness, and compassion” (p. 141).

The obvious importance of the educator in the presentation and modeling of good character generally is recognized, but how do schools teach values? Kozol (2001) reflects: "The discussion is inevitable and unavoidable, because schools and the adults who run them, model and teach with every action, every policy” (p. 128). It is 
understood that one of the most effective means of moral development is in fact modeling by educators. One author addresses this issue:

Of course, the success of this approach [informal character formation] depends highly on teachers who understand the value of these ideas. In a practical sense, this teacher variable could be handled through selection, training, and evaluation processes already in place; however, teachers would have to commit to emphasize character education and find their own particular ways to encourage it. Character educational theory should address the issues associated with this process at each point in the selection, training, and evaluation of teachers and in conceptual models needed to bring about the highest levels of success in helping students experience realistic character teaching (Williams, 2003, p. 30).

The impact of modeling as a tremendously effective means of character training should also involve parents, teachers, administration, and the community at large. Character education is described by one author as a "holistic enterprise" (Davis, 2003, p. 48).

Understanding the significance of the means by which character education is presented to students, the need for consistent instruction and discipline is recognized. Fully integrated character in all aspects of learning and real life experiences seems to be the consensus of the literature. Apart from this, the commitment felt by those involved is significant. Ryan \& Bohlin (1999) predict, "Character Education can take root in a school only when the administration, teachers, and staff believe in what they are striving to accomplish" (p. 159). Williams (2003) states further: "Real character education is not preached at you, but rather lived with you” (p. 9). Complete integration of moral development provides continuity from which a sound basis of character development can be realized. This is expressed by Anderson (2000) who said, "Character education cannot be taught as a separate curriculum, but must be entwined in all curriculums” (p. 140). 
The recognition of the importance to provide opportunities for students to demonstrate good character is found to be a vital component in the development of programs purposed for character formation. Areas of the literature report the observation that the development of moral ability shares important similarities with the development of conceptual thinking (Crawford, 2001). Thus, many models of character education focus on cooperation, compatibility, and genuine respect. Martinson (2003) states, “The key to stimulating the moral and ethical imagination lies in bringing ethics to a level to which they [the students] can readily relate” (p. 15). One experienced teacher remarked, Most books on character education involve lecture format and group games, etc... That is okay, but real character education won't be internalized outside real experiences of the concept itself. The best way to help students develop character is to place them in real situations that encourage them to dig deeper and go further by themselves, not just hear about it - but act on it” (Williams, 2003, p. 27).

Providing this real life experiential context for moral development is found to be a significant factor in procuring long-term results. Students given the opportunity to show good character and personal responsibility have demonstrated a more intense commitment to character (Lickona, 1993).

One positive outgrowth of character education is the improvement of academic standing. As students are taught the meaning and value of diligence, attentiveness, persistence, etc... and behavioral standards are enforced, students tend to score significantly higher on various means of assessment. Ryan \& Bohlin (1999) observes that "one of the many benefits of character education in the schools is that academic performance goes up with good behavior.” (p. 11). 
Aristotle is said to have summarized the essential truth behind the character education model. He said, "We become just by the practice of just actions, selfcontrolled by exercising self-control, and courageous by performing courageous acts” (in Wynne, 1991, p. 143). According to this definition, true character education must function as not simply somatic learning, but also episodic. This same idea is reflected in the works of the author Crawford who considers character education to be a stimulant for the discovery of "significant reference-behaviorisms" (Crawford, 2001, p. 121).

Finally, educators must wrestle with the fact that theoretically, according to Gilness (2003), “Character Education cannot be isolated, codified, and packaged into tidy little instructional units in a how-to manual” (p. 243). The meaningful application of character education involves much time and effort. It is vital that programs of purposeful character development be defined and the underlying motivational premise of such programs explored. This author further questions, "If education ignores the value and moral aspect of the human psyche, where will society find citizens able to make moral decisions?” (Gilness, 2003, p. 245). The Christian educator's philosophy of character education is clearly defined in Scripture and thus the Christian framework of educational process can indeed produce a relevant moral standard with confidence.

\section{Significant Factors}

Education is only one factor in the development of a healthy character in a child. Other factors are parents, family life, learning environment, and adult mentors. One of the most salient problems faced by American students is the societal demise of the family. The turbulent marital conditions of many families and the multitude of broken 
homes and blended families have tremendously affected the lives and values of many of today's youth. The sad fact is, as one author reflected, "For many students, character and virtues will be acquired in school - or not at all” (Kagan, 2001, p. 51). Dobson (1992), esteemed child psychologist, states that "respectful and responsible children result from families where the proper combination of love and discipline is present (p. 186). Unfortunately, in many familial situations, parents cannot offer what a child so desperately needs, love and consistent discipline.

The disintegration of marital status is perhaps the most significant factor influencing the moral development of American students, but is not the only problem. The fragmentation of family life has also contributed to this moral decline and is present even within Christian circles. This is reflected by Ryan \& Bohlin (1999) who states, "Where once family members looked to one another for their social life and entertainment, now the modus operandi is to 'do your own thing'...these changes make for a very different American family, one in which the ties are fewer and looser” (p. 119). Glanzer (2003) reports, "Parents and civil society face tremendous obstacles to nourishing their children's character because children's lives are too fragmented especially if they attend a public school” (p. 295). Although, he concedes: “Americans do not look to moral education programs in public schools as the primary source of their children’s moral sustenance” (Glanzer, 2003, p. 294), since they also do not consciously provide for that moral development in their own home.

The issue of safety in the public school system has also become an area of significant concern for parents in recent years. Schools have been described as "morally 
dangerous places for children” (Kozol, 2001 p. 128). One of the best indicators of academic and social success is the learning environment in which the student is educated. The results from a recent study revealed patterns which have been attributed to the success of moral development. The first and most prevalent of these was determined to be the teacher's ability to provide "a safe and desirable character education environment" (Williams, 2003, p.13). The idea that children could be physically unsafe in their learning environment would naturally void all possible attempts of character education: “Children do not develop morality in a hostile environment” (Williams, 2003, p.18).

In viewing the natural development of moral astuteness in a child, the importance of adult mentors cannot be overemphasized. The ability of parents and teachers to communicate and model character is of the utmost importance in a child's development. Genuine moral ability is reflective of the mentors in a child's life. Weissbourd (2003) asserted:

The moral development of students does not depend primarily on explicit character education efforts but on the maturity and ethical capacities of the adults with whom they interact- especially parents, but also teachers, coaches, and other community adults (p. 6).

Many parents can no longer entrust the public school system to provide such mentors so they themselves take on that primary role in home education. Others say they do not have confidence to entrust their child's emotional and moral development, let alone their safety and academic advancement to local school systems. Parental involvement and school choice have recently increased in their popularity as a result, while Christian parents, in many cases, have abandoned the public schools in favor of other educational options. 


\section{Evaluation of Character Education Models}

From a pedagogical perspective, if consensus could be reached in defining what constitutes appropriate instructional practices in the field of character education, it would also be necessary to determine if the students are demonstrating those character qualities. As far as character and virtue can be measured, appropriate methods of assessment and evaluation would have to be developed. This would help educators ascertain the effectiveness of a particular program and would provide useful information for future character education planning and decision-making. Yet, can the development of character be accurately and effectively measured? One would argue that character is deeply personal and thereby difficult to evaluate by traditional means of assessment.

The recent revival of character education has been a positive attempt to recapture moral training in public schools. However, some traditionally held character traits have been divorced from the Christian ethic and distorted into politically correct, humanistic virtues. This apparent screening for religiosity in any form is made clear by the views of Nash (1997): "I believe that if the virtues of humility, faith, self-denial, and charity are to have any functional utility in secular educational institutions, and in a democratic society, then they have to be 'decoupled’ from their religious roots and secularized” (p.166). Another author suggests that this type of thinking is practiced by educators who are "trying to teach as much civic and common ground morality as they can without crossing over church-state boundaries or promoting too much of a controversy of theology or metaphysics in the public schools” (Glanzer, 2003, p. 294). Christians who believe that the education of a student's mind is closely aligned to the development of 
wisdom and spiritual maturity, need to carefully approach secular character education materials with prayerful discernment.

Although there is little consensus about what specific curriculum and methods are best applied to accomplish the task of character formation, studies have concluded that there are broad parameters with which to measure the effectiveness of a character education program. As a result of much analysis and research, a team of character education advocates developed one such list of eleven criteria that professionals can use to plan and in fact evaluate an existing character education model (Lickona, Schaps, \& Lewis, 1998):

- Character education hold, as a starting philosophical principle, that there are widely shared, pivotally important core ethical values, such as caring, honesty, fairness, responsibility, and respect for self and others.

- Character must be comprehensively defined to include thinking, feeling, and behavior.

- Effective character education requires an intentional, proactive, and comprehensive approach that promotes the core values in all phases of life.

- The program environment must be a caring community.

- To develop character, young people need opportunities for moral action. Young people learn best by doing.

- Effective character education includes a meaningful and challenging curriculum that respects all learners and helps them succeed.

- Character education should strive to develop intrinsic motivation. 
- Teachers must become a learning and moral community in which all share responsibility for character education and attempt to adhere to the same core values that guide young people.

- Character education requires moral leadership. For character education to meet the criteria outlined thus far, there must be educators who champion the effort.

- Programs must recruit parents and community members as full members. Parents are the first and most important moral educators of their children.

- Evaluation of character education should assess the character of the program, the staff's functioning as character educators, and the extent to which the program is affecting children.

The intention of these guidelines is to identify the central tenets of a successful character education program. Since this evaluation tool has been developed through a significant amount of research in the field of character education and current practice, the validity of the criterion is established. This evaluation tool is of great benefit to those seeking to implement a character education program specific to their sphere of instruction.

\section{Historical Perspectives}

The concept of private schooling and home education is not a new idea in the history of American education. Long considered a private matter in North America, education is not even mentioned in the U.S. Constitution (Basham, 2001). Throughout history, societies have home-educated (Gordon \& Gordon, 1990) and schooling at home has been practiced throughout American history. Instruction typically came from the parents or through the employment of a private tutor. The first colonists' home educated their children out of necessity, since settlement schools were not yet established. Yet, 
even after local schools were formed, the resulting rural, one-room schoolhouses were often church run, religiously based, and always private, community schools (Loria, 2002).

At this time in the progression of American education, the historical Christian underpinnings and societal context for Biblical morality served as the prime purpose of education. The primary goal of schooling, especially among the original Puritan and Separatist Colonists, was to foster religious devotion (Schindler, 1987). Inherent in the Reformation's concern that everyone be able to read a Bible, the schools were aimed towards the instruction that would make this possible. Liermann (1999) states:

Three hundred years ago, Christian education and character education could be synonymous to education. Moral growth was viewed as the driving force in the initial establishment of American schools. The colonists believed that personal encounter with Scripture ensured individual salvation and ethical citizenship (p. 6).

The morality which was traditionally taught in early American schooling was based solely upon one primary authority: "The Bible served as the primary textbook for reading and the daily lessons reinforced a commitment to moral codes of behavior based upon the Scripture” (Algera \& Sink, 2002, p. 163). American society provided a moral basis on which to teach relevant ethics, yet this is no longer true.

With the establishment of compulsory education in the 1870s, the industrial revolution in America influenced the development of government run places of instruction. The school bell to change classes was the most obvious correlation between the factory model, which rang a bell to signal the shift changes at the factory. There is, 
according to current research, indication that early home education and one room schools produced a better education that the abiding factory model school (Loria, 2002).

Even after the institution of compulsory education, home education and, in remote areas, the community-run private schooling model continued to be used. Notable home educated individuals in American history included presidents such as George Washington, John Quincy Adams, Abraham Lincoln, Woodrow Wilson, and Franklin Delano Roosevelt. Other successful products of American home schooling include inventor Thomas Edison, General Robert E. Lee, civil rights activist Booker T. Washington, writer Mark Twain, and industrialist Andrew Carnegie (see Basham, 2001). Because public schools still rendered a very Protestant influenced educational experience, most American students attended a form of government run institutionalized education during the years up to World War II and beyond.

It was not until the early 1960s that home education was again promoted as a legitimate response to compulsory education. This movement, at the beginning, traced its theoretical lineage to the libertarian Left, as promoted by the late teacher and humanist John Holt. Basham (2001) notes this; John Holt provided the leadership in advocating a radical movement that stressed educational decentralization and greater parental autonomy. This movement became known as "laissez-faire home schooling” (Hunt, 1981), a concept currently referred to as "unschooling” (Ray, 1999). Although the contemporary image of home schooling parents depict a homogeneous, deeply religious, socially conservative sub-group of the population, in the 1960s and 1970s most home school parents were members of the counter-cultural Left, principally advocates of New 
Age philosophies, ex-hippes, and homesteaders. State standards were eventually set in place mainly between the years 1975-1993. Bashan (2001) reports of the recent legality of home education: "In 1980, home schooling was considered illegal in 30 states. It has only been legal in all 50 states since 1993” (p. 4).

This same period of history witnessed a rejection of Biblical authority in the public education system with three famous Supreme Court decisions. These three rulings effectively removed all religious influences from government-run schools. In 1962 the Supreme Court Case Engel v. Vitale banned public schools from requiring recited prayers which was done previously in the public schools. The next year, 1963, witnessed the case Abington School District v. Schempp which forbade voluntary prayer from being uttered in schools. The third case was the famous, Murray v. Curlett which effectively removed Bible reading from state schools. It is suggested that the forced federal desegregation of public schools as an outgrowth of the civil right movement and the removal of the students from their neighborhood schools also resulted in the weakening of the attraction to the public school system for Christian parents (Algera \& Sink, 2002). In response to these major shifts in public education, many evangelical Christians withdrew their children from the public schools and this demand for an alternative to public education fueled the contemporary Christian school movement.

Also during the period of the 1960s and 1970s, within the public schools, more didactic forms of character education of the early $20^{\text {th }}$ century surrendered to the new values clarification approach (Raths, Hermin, \& Simon, 1966). This approach gave no basis for absolute truth and instead allowed and actually encouraged alternate realities 
(Kirschenbaum, 1977). Values-clarification was intended as an intervention to alleviate the values confusion of students by teaching these individuals to apply a process of 'valuing' in order to diminish comparison between absolutes. This ideological shift in the premise of educational theory coupled with the rejection of Christian practice and the authority of Scripture was the final catalyst of the exodus of many Christian students from public education.

During the 1980s and 1990s, some educators, who viewed the values clarification approach as morally relativistic and ultimately detrimental to the goal of character development, began advocating a return to character education (Lickona, 1991; Ryan, 1986; Wynne, 1991). Still, confusion as to what constitutes this new secular morality significantly increased the difficulty in the unification of the movement. Alexander (2000) expressed this secularization of moral virtue:

It does not follow that to be ethical or moral one must believe in God. But it does imply that one must believe that something is of value beyond one's self and one's community....To think of the absence of the sacred that is, its total absence, is to conceive a condition in which nothing excites horror. And in such a world, moral education cannot gain a foothold" (p. 366).

The attempt of the return of character education in public schools did little to impress the Christian parents who felt strongly that they were responsible before God for the training of their children.

The cost of taking Christian students out of the public schools was high. Not only were these Christian parents taking on the extra expense and time commitment involved in alternative Christian education and home schooling, in some instances they risked breaking the compulsory public school attendance laws that were in effect. Since home 
education and non-chartered Christian schooling options were, in many cases, not state sanctioned, as Ingersoll (1990) reminisces:

Some states went so far as jailing parents who sent their children to schools violating the restrictive guidelines; other states granted the schools virtual autonomy, believing that education is a protected religious activity. Many schools not subject to state regulation voluntarily submitted to nongovernmental accreditation from organizations such as the Association for Christian Schools International (p. 41).

The legal groups and national organization such as Home School Legal Defense and Association of Christian School International aided the long battle for state acceptance and by 1993 home education was legal in all fifty states.

\section{Christian School Movement Today}

By way of definition, one author defined the Christian school movement as, “specifically referring to conservative, mainly protestant, evangelical, and fundamentalist schools and generally does not include Catholic parochial schools or those sponsored by mainline Protestant denominations” (Ingersoll, 1990, p. 43). As previously explained, this movement was a response to the societal shift away from Biblical authority especially in the public schools. Most Christian schools are thus characterized as independent schools; they are independent in the sense of their freedom from state support and state control, but not free from accountability.

The Council for American Private Education (CAPE), indicate that there are presently $5,927,000$ private school students or $11 \%$ of the K-12 population. There are approximately 27,000 private schools [including parochial schools], comprising 25\% of all U.S. schools. Projected enrollment is on the rise through the year 2006 with 
secondary school enrollment peaking in 2008. Of these private schools, $90 \%$ are religiously oriented and have fewer than 300 students per school. Average tuition is $\$ 3,116$ and the myth that private schools serve the predominately wealthy is discounted by the report released by the Bureau of Census. This report stated that less then $25 \%$ of all private schools students come from families with annual incomes of $\$ 75,000$ or more (Council for American Private Education, 2004). Christian education tends to be academically rigorous with students commonly performing a grade level ahead of their public school counterparts.

\section{Home Education Movement Today}

The U.S. government defines home schooling as, "The education of school-aged children at home rather than at a school” (Linas, 1993, p. 1). Home education has grown into a national educational movement and has become a catalyst for change in education according to Kay (2001):

Home schooling, initially off the radar screen has in the last 30 years of its modern revival become a completely mainstream alternative to institutional schooling of any kind, public or private. No longer monolithic, home schooling is easily accessible, adaptable and responsive to its consumers...home schooling is the still extreme, but it is rapidly assimilating cultural prototype for inevitable reforms to public education in the coming decades, already in vigorous germination in the form of school voucher programs and charter schools (p. 28).

During the last two decades, the American public's familiarity with home education has evolved from a level of almost complete ignorance to one of widespread, if largely uninformed, awareness (Basham, 2001, p. 10). Feature articles on home schooling graced the covers and pages of prominent national publications (see Benning, 1997; Cloud and Morse, 2001; Kantrowitz and Wingert, 1998; Kay, 2001; Mauschard, 1996; and Stecklow, 1994) 
In the United States, various estimates suggest home education is growing at a rate between 11 to 40 percent annually (Ray, 1994; Cloud \& Morse, 2001, p. 49). In 1985, there were only 50,000 American home educated children; by 1992, there were 300,000 home educated children (Gutterson, 1993). In the fall of 1995, the U.S. Department of Education estimated that approximately 850,000 students were being home schooled. However, according to the national organization Home School Legal Defense Association, by the fall of 1996 there were 1.2 million home schoolers. To put this is context, the United States has approximately 50 million students attending 85,000 public schools and 26,000 private schools (U.S. Department of Education , 1996, table 5). Therefore, home educating families may comprise the equivalent to 2.4 percent of the school-aged population, although a more recent estimate places the total as high as 1.7 million, or 3.4 percent of the school-aged population (Rhodes, 2000). In comparative terms, the collective number of children being home schooled in the United States today, according to recent studies, exceeds the individual public school enrollment of 41 of the 50 states ( Ray, 1997).

The socio-demographic characteristics of home schooling families, according to one author, fit one of two categories: ideologues and pedagogues. The ideologues are mainly, but not exclusively, religious conservatives, while the pedagogues are preoccupied with improving their child's academic and social environment (Van Galen, 1991). According to reports in 2000, today 75 percent of American home educating families are practicing Christians (Livni, 2000). Importantly, home schooling families are almost exclusively two-parent families: "In order to home school, parents may need to dedicate a significant amount of time to schooling their children. Because of the time 
required, home schooling usually involves two parents - one who participates in the labor force and one who home schools” (Basham, 2001, p. 11).

\section{Contemporary Research}

Identifying the value of character education in relation to academic and social attainment is challenging. Hundreds of research studies have been conducted suggesting connections between an increase in achievement within the confines of proper disciplinary measures and religious instruction that centers on character development. Some analysts, however, are skeptical of the empirical evidence that exists: "There is no consensus on the effectiveness of these programs” (Revell, 2002, p. 422). However, proponents of character education as a means of educational reform, insist that the theoretical, methodological assumptions are sufficient without empirical support to sustain the validity of character education programs (Algera \& Sink, 2002). This problem of the lack of empirical evidence is addressed by many authors in the literature. Leming (2000) notes the significance of identifying a solid foundation on this domain: "While criteria for effective character education program development and implementation can be found, many character education programs fail to be grounded in a well-researched conceptual framework” (p. 82).

In response to this skepticism, many character education advocates have encouraged further study in the area of character development's impact on school performance. However, the effectiveness of character formation and moral development is difficult to assess. Hunter (2000) writes, for example, “There is a body of evidence that shows moral education has its most enduring effects on young people when they 
inhabit a social world that coherently incarnates a moral culture defined by a clear and intelligible understanding of public and private good” (p. 154). In spite of this perceived lack of empirical evidence, the National Association of Secondary School Principals (1996) met in the mid-nineties, issuing the following statement: "Schools must unabashedly teach students about such key virtues as honesty, dependability, trust, responsibility, tolerance, respect, and other commonly-held values important to Americans” (1996, p. 86).

The frustration of the evaluation of character education is that its effects are hard to measure apart from a longitudinal approach. In the Christian school, this is especially difficult, since the goals of character are coupled with the lofty goals of spiritual formation and maturity. One respected Christian school administrator addressed this problem, saying:

What developed in their lives during their years at Christian schools will not be fully evident until they are completely on their own, facing financial pressures, career stresses, relationship decisions, and later on, marital responsibilities. What happens then will indicate how deep and how strong their spiritual root systems have grown (Schindler, 1987, p. 7).

Since educational theory is primarily based on projections and assessment, when approaching character education, educators are called upon to be very creative in the assessment of student success.

Despite contemporary criticism many groups have taken a strong stand in support of the continuation and expansion of character education. The Josephson Institute of Ethics (1992) hosted a summit conference in Aspen, Colorado. A diverse group of ethicists, educators, and youth-service professionals convened to find ways to work 
together and boost their character education efforts. They created The Aspen Declaration on Character Education in which they affirmed: “The character and conduct of our youth reflect the character and conduct of society; therefore, every adult has the responsibility to teach and model the core ethical values and every social institution has the responsibility to promote the development of good character” (Josephson Institute of Ethics, 1992, p. 2).

Much qualitative research and a myriad of case studies have been documented in an attempt to demonstrate the value of character education. The account of one such case study is the story of Chicago's Mundelein High School. It is an example of one of the antidotal experiments that have shown tremendous results in response to the implementation of character training. Matera (2001), documents this successful, studentlead campaign in which a group of students, sick of their rowdy school, demanded to have moral and ethical instruction along with the regular curriculum. After character based behavior modification was implemented, the school climate changed dramatically and behavior incidents declined. Mundelein High School's case study, according to author Matera, leads one to the conclusion was that "there is no quick fix for the moral breakdown that causes students to shoot students or to take drugs, join gangs, or self destruct in other ways” (p. 79). Nevertheless, character education, he points out, more than metal detectors or police in the hallways, "has proven the most effective, long-term strategy that public schools can adopt” (Matera, 2001, p. 138).

Apart from character education studies, academic researchers and policy analysts are exhibiting more than a passing interest in home education. In June 2000, for 
example, the Peabody Journal of Education devoted a 300-page issue exclusively to the topic of home education with the theme: "The Home Education Movement in Context, Practice, and Theory” (McDowell \& Ray, 2000). In recent years, home schooled students are gaining admission and scholarships to the most prestigious universities. Institutions across the United States, including Harvard University, Yale University, Stanford University, MIT, Rice University, and the Citadel have admitted home schooled students (Leung, 2000). September 2000 saw the opening of Patrick Henry College, in Virginia, the first university established especially for home-educated students.

The most recent and comprehensive study of American home schooling was led by leading statistician and measurement expert, Dr. Lawrence Ruder of the University of Maryland. In 1998, Ruder (1999) conducted a study entitled, Scholastic Achievement and Demographic Characteristics of Home School Students. The Educational Policy Analysis Archives published the report of findings. The study measured 20,760 home schooled students in all 50 states. Rudner concluded: "Those parents choosing to make a commitment to home schooling are able to provide a very successful academic environment” (1999, p. 84). Rudner's findings, when comparing academic standing between home school, public school, and Christian school, found that overall, test scores for home-educated students fell between the $75^{\text {th }}$ and $85^{\text {th }}$ percentiles. Public school students scored at the $50^{\text {th }}$ percentile, while private school students' scores ranged from the $65^{\text {th }}$ to the $75^{\text {th }}$ percentile.

This study also found that 24.5 percent of home schooled students perform one or more grades above their age-level peers in public and private schools (Rudner, 1999). In 
fact, according to Ray (1997) of the National Home Education Research Institute, home schooled students in grades 1-4 perform typically one grade level higher then their public and private-schooled peers. However, by Grade 8, the average home schooled student performs four grade levels above the national average.

\section{Summary}

The face of American education in the $21^{\text {st }}$ century has experienced rapid transformation brought about by many contributing factors. Most disturbing among these are the humanistic secularization of public education and the internal purging of the Judeo-Christian foundation of morality and societal ethics. It is therefore significant to note the unique sociological phenomenon existing in response to this rejection of the religious underpinnings of American public education. The continual growth of Christian private schools and the increasing rate of home education (Ray, 1999; US Department of Education, 2001) indicate a movement away from public education, especially within the evangelical Christian community.

Concerned parents have bailed out of public schools, choosing rather to fund a private education for their children. Others accept the full responsibility of that education and seek to provide a learning lifestyle for their children in the form of home education. One prominent author noted, "homeschooling's most important lesson is that parental involvement is essential to a child's academic success” (Dobson, 2003, p. 204). Current trends reveal that a number of Christian parents feel they can no longer entrust the public school system with their child's potential, let alone their safety and academic 
advancement (National Home Education Research Institute, 2000). The exodus of

Christian students from the public education system is not an isolated phenomenon:

Public opinion polls show that confidence in the education system is at a 30-year low. Tangible proof of this is the growing number of children withdrawn by their parents each year from government schools; the percentage of families choosing independent, or private, schools has doubled in the past twenty-five years, while the popularity of home schooling is unprecedented and growing rapidly (Hepburn, 1999, p 4).

The issue of character education and spiritual training has been a significant factor in the emergence of both Christian schools and home education. For this reason it is necessary to examine the models utilized in character development in the Christian school and home education milieu in order to better serve the purpose for which Christian education was first conceptualized. 


\section{CHAPTER III: Research Method}

The research methodology utilized in this study was designed to examine and compare the role of character education in the Christian school and home education milieu. Therefore the study was conducted as a comparative, phenomenologicalqualitative research analysis. This particular research approach is based on the qualitative inquiry model which is characterized by its search for understanding of social

phenomenon (Sowell, 2001). This research design seeks to explain a pattern of relationships, which can be accomplished within a set of conceptually specified categories (Mishler, 1990). Qualitative research is most appropriate for the domains associated with new area of research inquiry. Thus, a phenomenological-qualitative research methodology was chosen for this study since it allows for observation and indepth interviews to generate patterns of continuity and contrast that ultimately embody the research constructs of this project. This method of constant comparison, originally advocated by Glaser and Strauss (1967), strongly influenced the analysis of the interview data collected for this study.

\section{Project Development}

In partial fulfillment of the requirements for the degree of Master’s of Education from Cedarville University, the researcher developed this project in cooperation with the study supervisors: program coordinator Dr. Stephen S. Gruber and thesis advisor Dr. Michael W. Firmin. The researcher, having been previously home educated, desired to develop a project in which the Christian home educating populace might be included. The researcher also wished to probe the philosophical depths as to the foundation of the 
various goals of Christian character education. A brief initial inquiry as to the importance and significance of character education in the course of Christian schooling brought about an enthusiastic response for the researcher. Thus, it was decided to pursue a project that examined character education in the Christian school and home education milieu.

The next step was to set the boundaries for the project and determine a research methodology that would lend itself to the specific needs of such an undertaking. Utilizing a qualitative research methodology seemed the most appropriate response in measuring the educational perspectives and importance of the implementation of character education within the chosen settings to be examined. The researcher thus pursued training in qualitative research through the Psychology Department at Cedarville University. Dr. Michael W. Firmin, department chair, graciously agreed to serve as the thesis advisor. The proposed thesis topic was thus approved by Dr. Steve Gruber and the Graduate Department in July 2004.

\section{Sample Criterion}

The researcher went about the arduous task of developing the criterion for the selection of a sample base. Consistent with internal validity protocol for qualitative research, a criterion-based method of sample selection was implemented. According to the criterion set forth in the checklist for interview sample selection (see Appendix A), interview candidates were first required to be professing, born-again evangelical Christians active in a local fellowship. 
A further research criterion was developed requiring that the Christian educators and home educating parents, in order to be eligible as a research subject, must affirm that they have previously been active in a teaching capacity for a minimum of five consecutive years. The subject also was required to be currently teaching in a full-time administrative, home educating, or teaching capacity. By requiring this longevity and current involvement in the milieu of home education or Christian schooling for subject candidates, the researcher was attempting to choose those individuals who would have the clearest views and most authoritative perspective on the reality of character training within their perspective educational settings.

The sample was limited to Christian educators serving in one of the four target schools chosen by the researcher. These Christian Schools included Bethel Christian Academy of Parma, Ohio; Christian Community School of Eaton Township, Ohio; First Baptist Christian School of Elyria, Ohio; and Open Door Christian Academy of Elyria, Ohio. The reason these schools were chosen as target schools, apart from the research criterion established, was primarily based on geographical location and upon the willingness of the administration and teachers to be involved in this study. The researcher was able to determine that the four schools were similar enough in structure, function, and demographics to be combined in the presentation of the data. Table 1 provides correlative profiling of these three schools in terms of grade range, enrollment size, affiliations, categorical locality, student teacher ratio, accreditation of Association of Christian Schools International, and student population ethnicity. 


\section{TABLE 1}

Profile Correlation Table of Christian Schools Comprising Interviewee Places of Employment

\begin{tabular}{|l|c|c|c|c|}
\hline \multicolumn{1}{|c|}{$\begin{array}{c}\text { CHRISTIAN } \\
\text { SCHOOL }\end{array}$} & BCA & CCS & FBCS & ODCS \\
\hline Grade Range & $\mathrm{K}-8$ & $\mathrm{~K}-12$ & $\mathrm{~K}-12$ & $\mathrm{~K}-12$ \\
\hline Enrollment & 280 & 220 & 180 & 643 \\
\hline Affiliations & $\begin{array}{c}\text { Assembly of } \\
\text { God }\end{array}$ & $\begin{array}{c}\text { Non- } \\
\text { affiliated }\end{array}$ & Baptist & $\begin{array}{c}\text { Non- } \\
\text { affiliated }\end{array}$ \\
\hline Locale Category & Urban & Rural & Urban & Urban \\
\hline Student/Teacher Ratio & $17.23 / 1$ & $15.58 / 1$ & $13.61 / 1$ & $15.09 / 1$ \\
\hline ACSI Accreditation & Yes & Yes & No & Yes \\
\hline $\begin{array}{l}\text { Ethnicity } \\
\text { Caucasian / Other } \\
\text { (Expressed in percentages) }\end{array}$ & $91.07 / 8.03$ & $97.22 / 2.88$ & $98.57 / 1.43$ & $93.31 / 6.69$ \\
\hline
\end{tabular}

In order for representatives from the home education community to be included in this study, the conditions for sample selection were somewhat similar to those applied to Christian educators. The home education interviewee was required to have previously home educated their own child for a minimum of five consecutive years in the state of Ohio. The researcher also required that the home educating family be currently home educating one or more students. It also was determined to use home educating families 
that were active as members of an area home school support group. In this way, the researcher determined the credibility of the home educator and their experience in the long term character development of their children within the framework of home education.

To further clarify the type of home educating family the researcher would include in the research sample, the criterion was expanded to allow only those home educating families that had a relatively long-term commitment to home education for their child's future schooling. This was important to the researcher since home education is done frequently by Christian families for a year or two with a struggling student and then abandoned. The families included in this study, therefore, are those having either had a student that was previously home educated through high school or families currently having a student home educated in high school. This commitment to home education was also measured by the researcher when selecting subject candidates. Before selection, the perspective family was asked if all school aged children, currently in the home, were home educated. The research subjects included in this study, with only a few exceptions, affirmed this was indeed the case.

\section{Research Tools}

After the abovementioned sample selection criterion checklist was completed (see Appendix A), the next tool developed by the researcher was the interview release form. This form was signed in advance of all interview sessions and thereby granted the researcher permission to record and reprint interview content (see Appendix B). The second research tool developed for interviewing was a detailed profile worksheet which 
also provided the researcher a place to record field notes (see Appendix C). This profiling of interviewees was useful in the development of descriptive statistics on the research sample. This subject profile allowed such things as years of teaching experience, educational level, number of children, instructional grade range, ethnicity, and family structure to be examined in relationship with the outcomes of the qualitative study. A scatter plot and several bar line graphs are included in the descriptive statistics portion of the research method presentation.

Because of the necessity for cooperation from the administration and teaching staff at four schools, the researcher developed a formal explanation and request for school staff participation (see Appendix F). A follow-up visit to the school usually came after the initial request of participation. This school visit included shadowing classrooms and meeting face to face with teachers. It provided the opportunity for the perspective interview subjects to sign the release form and set up a time for an interview with the researcher. The interview questions were made available prior to the time of the interview at the request of the interviewee. The researcher also made it a point to interview the administration at the beginning of the interview process and thereby acquainting them with the content of the research being conducted at their school. Recruitment of subjects from the home educating community was principally done through personal contacts and referrals. Home educating families that were considered for selection were contacted by phone. During these personal phone conversations the perspective interview subjects were informed of the project's scope and purpose. 
The central tool of the study, developed by the researcher, was the interview format. The semi-structured, in-depth interview consequently developed for the study was comprised of a series of eight questions. These sequential interview questions were prepared in consultation with the research advisor. Two corresponding versions of this research tool were developed so as to direct the questions meaningfully to the individuals from either Christian school or home education respectively (see Appendix D \& E). Because of the two versions of the interview, the following analysis of interview content will state both of the correlating questions in the event that they differ.

The first question, “Why are you involved in Christian education?” or "Why have you chosen to home educate your children?” dealt with the broader motivations and philosophical reason for their involvement in their perspective Christian educational alternative. It addressed the level of commitment and sacrifice that these forms of education entail and also provided the means for personal definition of the educational milieu. Because the educators in both Christian school and home education were very enthusiastic in their response as to the "why?" of their involvement, this first question served as a successful means of breaking the ice early on in the interview process. It was commonly referred to as "the loaded question" of the interview.

The second and third question addressed the educator's definition of character education and its importance and involvement in their educational program. The second question, "How have you come to understand the concept of character education in this context?” asked the interviewee to define and describe what they were referring to when they talked about character development within their educational context. The third 
question on the interview, "How is character development integrated at your school?” or "How is character education integrated in your curriculum and educational goals?” asked the educator to comment on the specific integration and implementation of their character training on both the theoretical and practical level.

Question four and five asked specifically how character education was implemented and the consequent models that had proved successful in their teaching experience. The forth question, "What model does the school implement to encourage the development of character?" or "What do you do to encourage the development of character? Is it formal or informal?” addressed the multiplicity of character development models and asked the interviewee to categorize them as either formal or informal. The next question, "What does the school actually do to produce character in the students?" or "What specifically do you do to produce character in your children?” probed deeper as to the precise means of character development they recognize as successful in their educational program.

Questions six and seven concentrated on what expectations were present and what means of evaluation were used to determine success in the development of character. In question six, "What is the school's expectation of the student in regard to character?" or "What is your expectation of your child in regard to character?" the researcher was attempting to identify the expectation or standard against which character is perceived by the interviewee. Question seven addressed the means of evaluation or measurement used as an indicator of success. This question therefore states: "What evidence in terms of outcomes demonstrates that you have successfully cultivated character?” This query 
focused on the positive signs of character that can be practically perceived and thus reported as an indicator of character development.

The final question was open ended and served to invite further discussion between the interviewee and the researcher. The question was: "Is there anything else that you would like to discuss or would recommend I ask in future interviews?” Ending the interview in this manner provided the opportunity to dialogue on related topics and also to go back and converse on a previous question. Although not many of the interview subjects took advantage of this opportunity, the question was still a valuable element in the construction of the interview.

The demanding task of scheduling and interviewing for the researcher was soon eclipsed with the necessity to transcribe recorded interviews. The researcher developed an interview transcription template (see Appendix G \& H) which provided the structure to correlate the questions of the researcher with the interview responses. Secondly, it provided a place in which the interview number, subject classification code, date of the interview, interview type, and footnotes might be clearly presented. These various classification and numbering systems corresponded to a confidential interview subject listing and paralleled the release forms with interview subject signatures. 


\section{Participants}

A full cross-section of individuals was interviewed for this research project. Four target schools were selected based upon a number of factors. Those selected to be included in this study were members of the administration and teaching staff. These included teachers, teachers who were parents of Christian school students, and home educating parents. Participants of this research project comprised of fifty-two educators from northeast Ohio $(\mathrm{N}=52)$. Twenty-six of said interviewees represented Christian educators currently teaching in Christian schools $(n=26)$ and twenty-six represented a selection of experienced home educating parents $(n=26)$. The span in the number of years of experience was larger within the Christian educating professionals than with the home educators. As seen in Table 2, in accordance with the research criterion, no less then five consecutive years of teaching experience in the Christian school sector was permitted. The range in years of experience was found to be from five to thirty-seven years with an average mean of over sixteen years of Christian educational experience of subjects teaching in a full time capacity.

The difference between the mean average of the Christian school educators and home educating parents, expressed in years of experience, was found to consist of only two years difference as expressed in Table 3. Consequently, the researcher found that the

years of experience teaching in home education is therefore dependent on the number of children in the family. This correlation between number of children and years of home educating experience is presented later in this section. Home education interviews commenced in August 2004 and were the first set of interviews to be completed by the researcher. 


\section{TABLE 2}

Sample Profile of Years of Teaching Experience* of Christian Educator Interviewees $(n=26)$

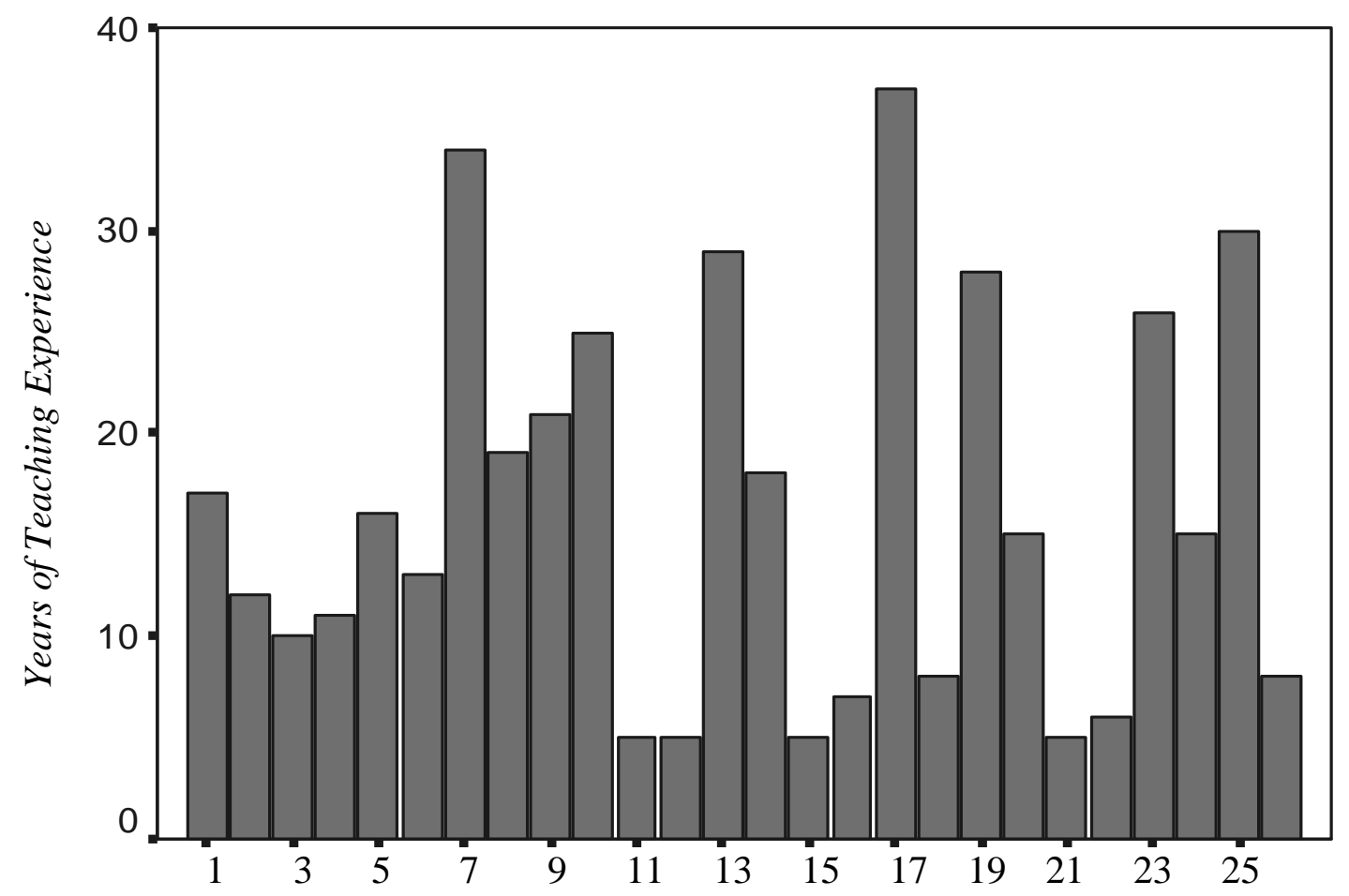

Research Subject Interview Numbers $(n=26)$

\begin{tabular}{|l|c|c|c|c|c|}
\hline Characteristic & $\boldsymbol{n}$ & Minimum & Maximum & Mean & Std. Deviation \\
\hline $\begin{array}{l}\text { Years of Teaching } \\
\text { Experience }\end{array}$ & 26 & 5.00 & 37.00 & 16.3462 & 9.74 \\
\hline
\end{tabular}

*Consistent with internal validity protocol for qualitative research, a criterion-based method of sample selection was implemented whereby subjects were required to have taught for a minimum of five years in order to participate in this study.

In the set of Christian school interviews, at all four target schools, members of the administration were included in the interview process and represented a 2:13 ratio of the Christian school interviews. In the home education milieu, the primary teacher was selected to interview. Typically, the primary teacher in home education model is the stay-at-home-mom. This was the case for the majority of the interviews conducted in this 
study. Female subjects comprised the entire home education sampling. The number of male and female educators included in the Christian school sampling was seven male teachers and nineteen female teachers which was reflective of the actual ratio within the target Christian schools.

\section{TABLE 3}

Sample Profile of Years of Teaching Experience* of Home Educating Interviewees $(n=26)$

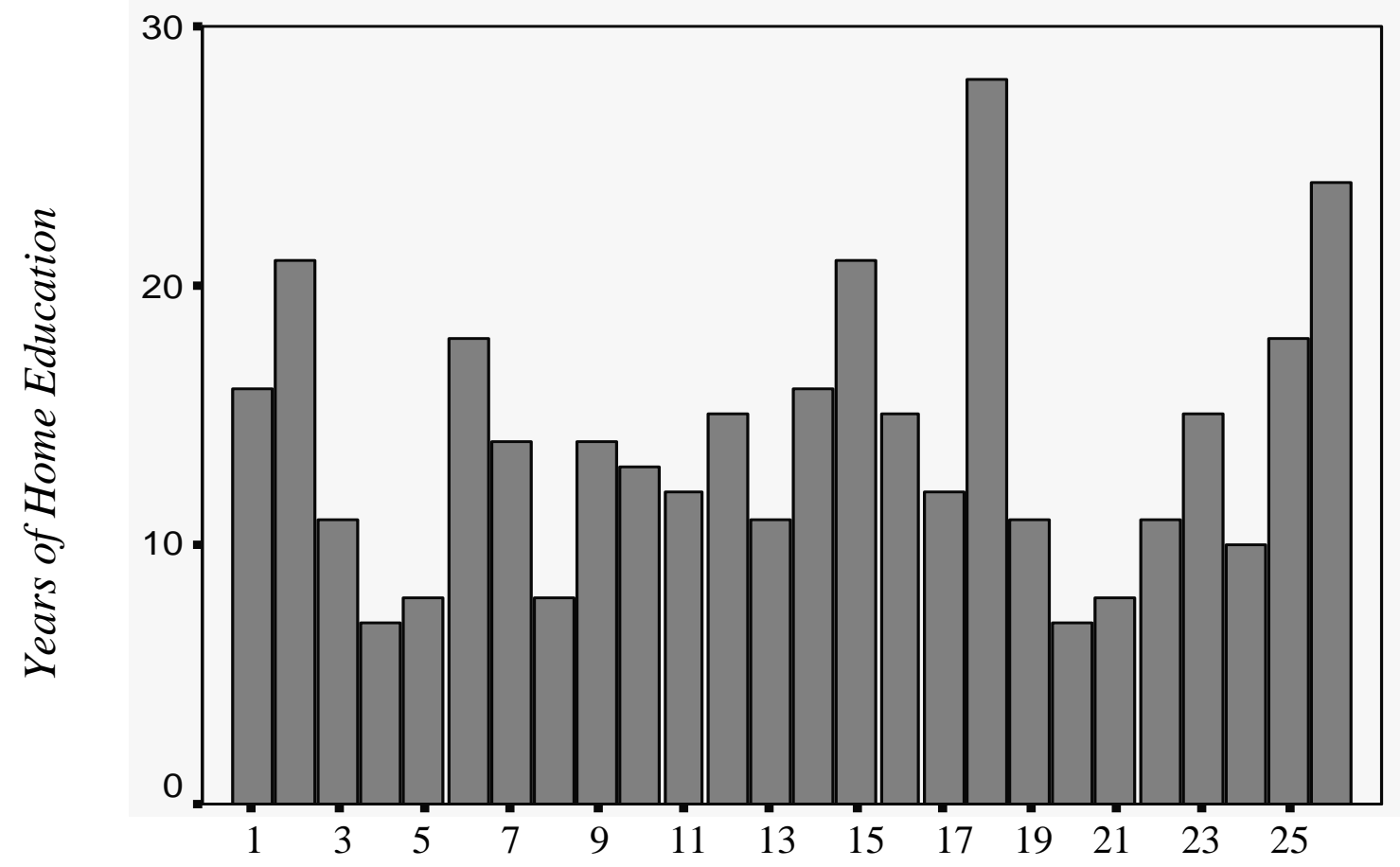

Research Subject Interview Numbers $(n=26)$

\begin{tabular}{|l|c|c|c|c|c|}
\hline Characteristic & $\boldsymbol{n}$ & Minimum & Maximum & Mean & Std. Deviation \\
\hline $\begin{array}{l}\text { Years of } \\
\text { Home Educating }\end{array}$ & 26 & 7.00 & 28.00 & 14.0000 & 5.35 \\
\hline
\end{tabular}

*Consistent with internal validity protocol for qualitative research, a criterion-based method of sample selection was implemented whereby subjects were required to have taught for a minimum of five years in order to participate in this study. 


\section{Descriptive Statistics}

Religious affiliations of the interview subjects varied widely. A large variety of evangelical denominational backgrounds were represented. All subjects were chosen in compliance to the research criterion that the subject be a born-again, professing evangelical Christian active in a local fellowship. The home education subjects provided two exceptions to the evangelical nature of the religious affiliation of the sampling. One family expressed themselves to be non-evangelical/non-denominational in their affiliations, while another was a Catholic family who were born-again believers. The Christian educators, who were not as carefully screened by the researcher, were nonetheless hired under specific requirements by all four Christian schools that they be born-again believing Christians, active in a local fellowship, and that they demonstrate Christ-like character in word and deed.

The socio-economic standing of the fifty-two research subjects included in this qualitative study signified that they were middle to upper class. The home educating families interviewed were all one income families. A number of the home educating mothers had previously left lucrative positions to home school their children. The Christian school educators, with a few exceptions of single parents and unmarried individuals, all were the second incomes in their family. The income they earned at the school was, in many instances, not sufficient to be the only income in the family. The cost of tuition for a Christian school education and the cost of educational materials for the home educating families rendered the middle to upper class levels of this sampling somewhat immaterial. 
One area that the researcher was eager to correlate was the level of educational attainment held by the interviewees in both the Christian School and home education venues. The subject profile served as the reporting tool in which the researcher documented the subject's highest level of academic attainment. The results of comparison are expressed in Table 4. The comparison is indicative to the fact that many home educating parents value higher education. More then half of the home educating

\section{TABLE 4}

Comparative Sample Profile of Interviewee's Level of Educational Attainment $(N=52)$

Home School Parents

\begin{tabular}{|c|c|c|}
\hline Educational Level & $\mathbf{n}=\mathbf{2 6}$ & $\mathbf{n}=\mathbf{2 6}$ \\
\hline Only High School Diploma & 8 & 0 \\
\hline 2-Year Associates Degree & 5 & 0 \\
\hline Bachelor's Degree & 8 & $20 *$ \\
\hline Master's Degree & 4 & 6 \\
\hline Ph. D & 1 & 0 \\
\hline
\end{tabular}

Parents included in the research study have received a four year degree, a master's degree, and in one case a doctorate. Conversely, a significant number of those interviewed as home educating parents have not earned a bachelor's degree, but simply a high school diploma.

The Christian school educators' levels of educational attainments were somewhat typical in the results. The findings mirrored the fact that the minimal requirement to 
serve as an educator is a Bachelor's degree. Members of the school's administration that were interviewed by the researcher tended to be those that held higher levels of educational attainment. Only six of the Christian educators, many of whom were in positions of administration, held a Master’s degree. Although many of the Christian school educators go beyond the Bachelor's degree earning continuing education credit to maintain state certification or ACSI accreditation, most were found to be content with the minimal requirement of a Bachelor's degree.

For home education to work, the two-parent home typifies the ideal and indeed the standard. It is very difficult to home educate without a strong two-parent family structure. However reflective of American society's culture, within the home education sampling of this research, two interviewees represented single parents from long term separated or divorced situation. The Christian educators, interviewed as the other half of the research population, with the exception of the never married, single teachers, comprised overwhelmingly two-parent homes. There was only one interviewee teaching in the Christian school that was divorced.

The number of children being home educated within the home education sampling was yet another area of interest that emerged from the subject profiling of the interviewees included in this research study. The majority of those home educating had large families. Table 4 describes the range of number of children in the home educating families interviewed in this study. The number of children within the home educating subjects immediate family ranged from one child to twelve. A single child being home schooled was the minimum, while twelve children provided the maximum with three 
adult children that were previously home educated through high school. Overall, the home education sample base of twenty-six families embodied a total of one hundred and thirty home educating students.

\section{TABLE 5}

Scatter Plot of Number of Children in the Home Educating Households of Research Sample Population $(n=26)$

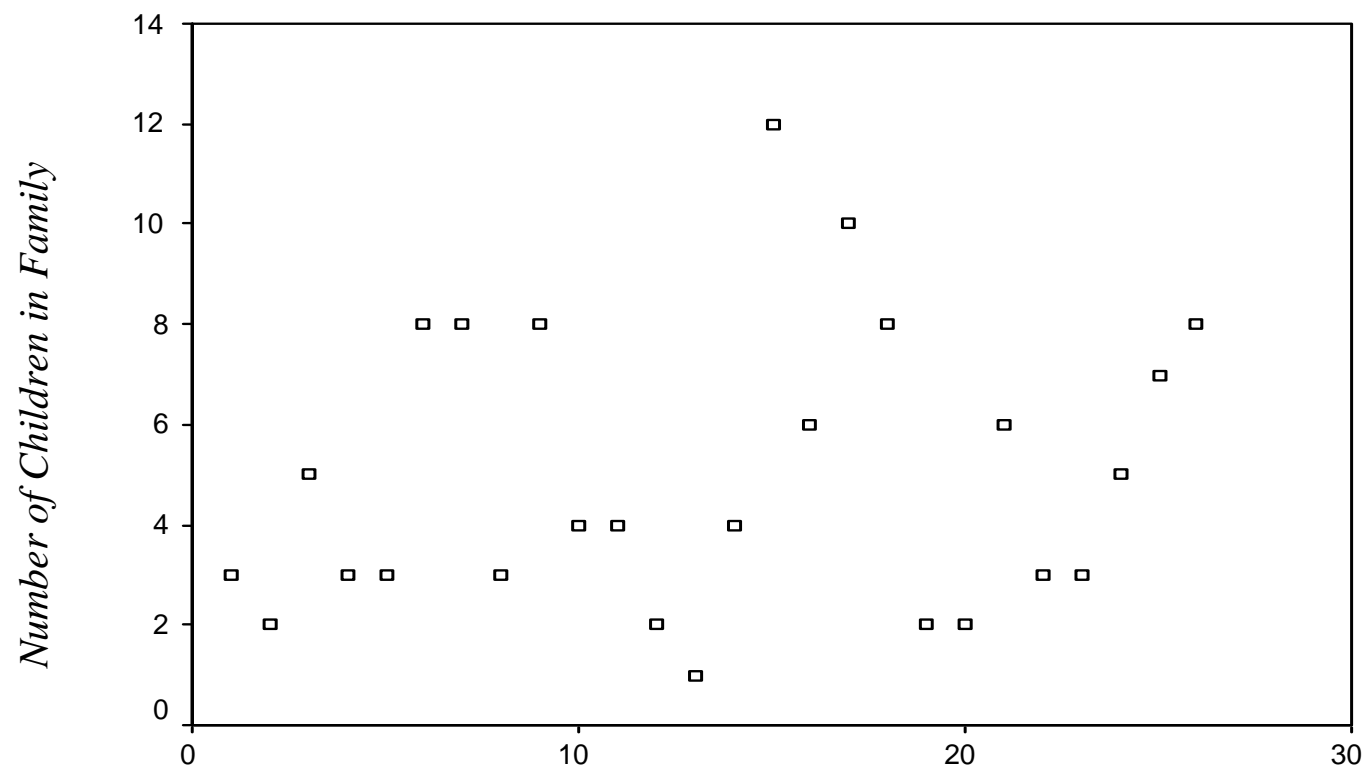

Research Subject Interview Number $(n=26)$

\begin{tabular}{|l|c|c|c|c|}
\hline Characteristic & $\boldsymbol{n}$ & Minimum & Maximum & Mean \\
\hline $\begin{array}{l}\text { Number of Children per } \\
\text { Household * }\end{array}$ & 26 & 1.0 & 12.0 & 5.0 \\
\hline
\end{tabular}

*Interviewee sample base of 26 families is representative of over 130 home educating students 


\section{Interview Process}

The data collection process of the research study extended throughout an academic school year and all interviews were conducted by the researcher. Initially, a screening process determined if the subject candidate would meet the research criterion set forth at the formation of the research venture. After the eligibility of the interviewee was determined, the researcher used a semi-structured interview format as the primary means of gathering data. The researcher met with educators after school hours to conduct and record the interviews. All interviews were recorded using a hand held micro cassette recording device. The researcher supplied a copy of the interview questions for the interviewee and read aloud the questions for the recording. The researcher, when conducting the interviews, allowed the interviewee sufficient time to respond and redirection questions were occasionally added at the researcher's discretion. These interview sessions with educators and home educating families also included shadowing classes, reviewing the specific school application process, inspecting curricular materials, and observing student behavior.

After coding and analyzing the data, the researcher returned to selected individuals with additional follow-up questions regarding their initial responses or to further deal with individual experience. This last round of repeat interviews and followup questions were conducted with representatives from both research groups. This process was purposed to gather additional data with particular individuals believed to be key informants. These follow-up interviews were designed to clarify and expand upon the previous data gathered and were uniquely focused on the individual being 
interviewed. These follow-up questions were conducted as the final stage of the interview process.

A small number of these follow-up interviews were structured as group discussions and many included only one further question directed at specific individuals. This group interview was purposed to address specific issues that had emerged in the qualitative coding as a result of previously gathered data and to pursue new areas of inquiry suggested by the interviewees in response to the last question of the interview: "Is there anything else you would like to discuss or would recommend I ask in future interviews?” The responses to these further questions were transcribed at the end of the individual subject’s original interview (see Appendix G \& H).

\section{Cataloging Interviewee Responses}

Throughout the entire interviewing process, the researcher documented running commentary, or field notes, that later aided in the process of coding the data and the generating of research results. A careful method of numbering the interview subjects and subsequent release forms, subject profiles, and field notes was developed by the researcher. Since these interview tools were intended to provide more quantitative data that would further define the results of the qualitative research, it was important to document them by date, order of transcription, and population category.

A numbering system was developed to indicate the order of transcription, interview number, and whether the interview was to be included in the Christian school or home education interviews. The interviews from the Christian school were numbered 
101-CS to 126-CS, while the home education interviews were numbered 101-HS to 126-HS. In addition, the interviews were labeled by date, order number, and interview type. It was important to correlate all interview material by subject code and number in order to remove all names from qualitative coding procedure. This was also amenable to the insertion of the transcribed interviews in the appendices, given that all names were removed and replaced with subject codes.

\section{Qualitative Coding of the Data}

After the researcher completed all interviews, catalogued the micro-cassettes, numbered the field notes, and systematically transcribed the interviews, the data was then reviewed by the researcher and the results analyzed to determine patterns of response. An inductive process of coding was used, deriving categories and themes from the data itself (Weber, 1990). This inductive approach to data analysis resulted in the emergence of four broad themes or grounded theory. A thematic categorization was then utilized to identify the central themes from the first round of interviews and this information was then tested and revised through analyses of succeeding group interviews.

In the initial examination of the collected qualitative interview data, inductive methods of analysis were used to draw out those broad themes that presented themselves upon careful re-examination of interview content. These surfaced from transcribed interviews, field notes, and follow-up interview responses. These potential themes were then organized and evaluated in relation to one another in order to develop from them possible constructs for the project's conclusions. A skeletal outline was then developed 
to serve as the first outline of results. Those elements of analysis that were unable to be adequately supported by data collected by the researcher were discarded or revised.

The four large areas of inquiry emerged in this initial stage of qualitative coding were as follows:

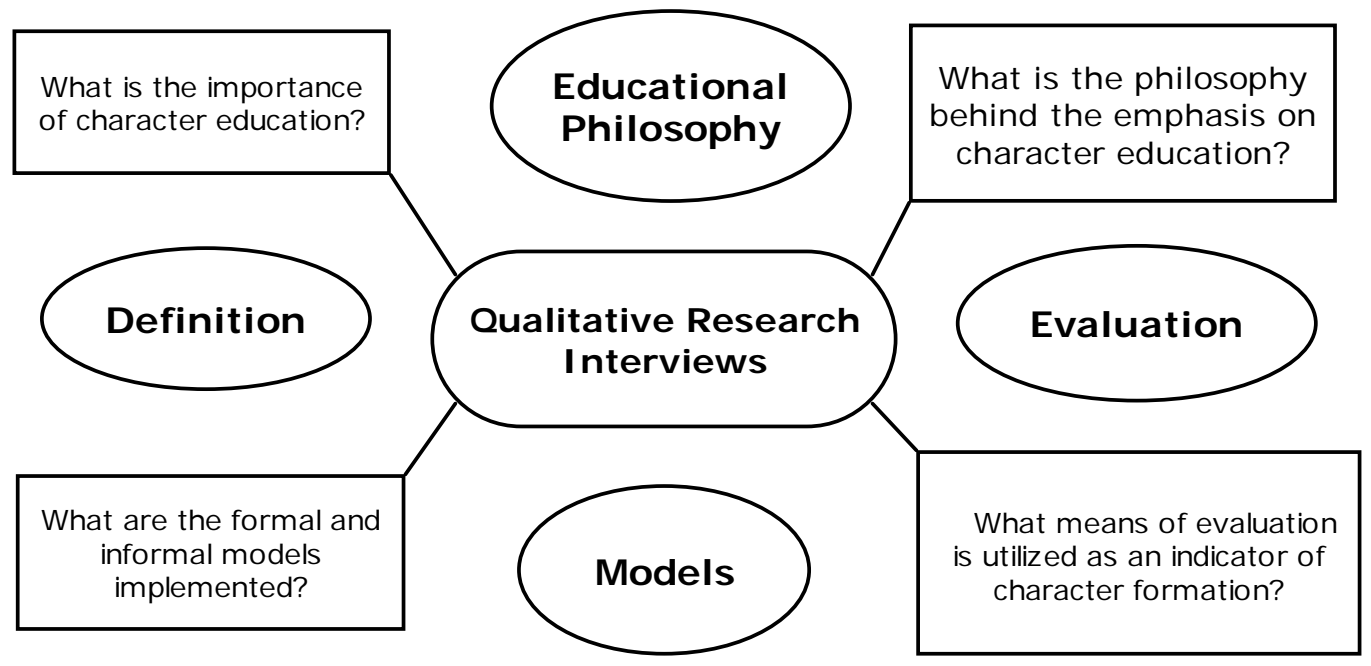

The first main category of response clearly present in the interviews was the definition of terms and perceived importance of character education. Secondly, the next apparent central theme to present itself as a common factor throughout the interview responses was the philosophical basis for Christian character education within the respective milieus in which the educator operated. The third broad category deemed worthy of consideration when conducting the qualitative coding was specific models and methodology unique to the formal and informal instruction of character education within the respective settings of Christian school and home education. The fourth and final emergent cluster to form from the research data was the proposed means of character education evaluation and the perceived indicators of the success of the implementation of character development. 
Taking these four areas of inquiry to the transcribed interview sets from the Christian school educators and home educating parents, the researcher used a color coding system to organize potential themes within the four broad categories. The first category, definitions and importance, was coded red. The second category, philosophy of character education, was coded green. The third category, methodology of the implementation of character education, was coded yellow. The final category, means of character education evaluation or empirical evidence of the development of character, was coded blue. After this initial coding was completed, the researcher combined all interview excerpts in each category and developed secondary themes within each of the four broad themes as subcategories. Consequently, the research results followed the pattern of an overarching structure of four broad themes from which all other coding results related.

\section{Limitations}

The research parameters set forth by the project design prevent the researcher from making any pragmatic statements that would indicate either the Christian school or home education milieu as being superior to the other in the area of character formation and development. The project's purpose is to provide a phenomenological perspective on the character education practices in both educational settings. Therefore, the comparative nature of this research project is not to commend one over another, but instead to critically observe the differences and make note of those models and methodology that have been proven successful in that specific educational environment. 
In order to increase the study's external validity, the researcher chose to select a sample base that was representative of a wide scope of individuals with varying backgrounds in accordance to the requirements of the sample criterion. These efforts to create a large sampling of twenty-six educators representative of four Christian schools and twenty-six home educators was meant to expand the legitimacy of the project results. The researcher took pains to include those individuals that would enhance the demographics of the research base. However, one cannot state that the findings of this research project can be generalized to apply to every Christian school, nor to every Christian home educating household, in every region of the United States. The researcher is confident, however, that every effort was made to present a clear representation of research data and to ensure internal and external validity from the project's very inception. 


\section{CHAPTER IV: Qualitative Findings}

The researcher's analysis of the qualitative data supplied by the in-depth, semistructured interviews conducted in this study resulted in the emergence of two major propositions of comparison: similarities and differences. The similarities between the approach to character education in the Christian school and home education milieu resulted in the materialization of four major similarities between groups. These similarities included, first, a profound commitment to the respective educational setting; second, a high estimate of the importance of character education; third, a foundational dependence upon Biblical authority; and fourth, a similar educational philosophy based upon the training of the "whole man." The various differences found between the Christian school and home education milieu in regard to character education appeared to fall within six categories of comparison. These six differences included principally the educational environment; the accountability within the educational process; character traits emphasized; relationship between formal and informal applied teaching models; evaluation of character development; and finally, differing perspectives on the outcomes of character education.

\section{Profound Commitment}

The careful analysis of the qualitative data supplied by interviews of twenty-six Christian school educators and twenty-six home educating families resulted in a unique connection between groups in regard to a shared sense of divine calling and personal gifting. This first and most apparent similarity between groups, overwhelming represented in the interview content, was the belief of these educators that they were 
called by God to teach in their respective educational setting. All those interviewed attested to some sense of "calling" or higher purpose in their chosen educational vocation, whether teaching in the Christian school or home education milieu. Those interviewed also expressed an appreciative understanding that God had uniquely gifted them in the area of teaching and had ordered circumstances to bring them into their present position. One veteran of thirty-seven years of Christian education said, "It is no accident those of us who emerge in the Christian education scene, because God sometimes has to go through a variety of convoluted was of getting us here.”

The persistent response in the interview data of a sense of divine calling and purpose was expressed in a variety of ways: it was referred to as "a definite calling from God on my life,” and "the Lord's leading.” It was also expressed as a sense of commissioning with such phrases as, "I was sent by God to minister here," "I was prompted by the Holy Spirit,” and "The Lord directed me.” One Christian school educator reaffirmed this assurance of her calling with the statement, "I know, that I know, that I know, that I belong here.” A home educating parent said, "My husband and I really felt called by God to home educate our children.” Another interviewee related her calling to that of a calling to other lands as a missionary when she said, "I felt a deep calling. Just as a missionary is called into the mission field, I was called to a lifetime of ministry in Christian education.” All such statements indicate to the researcher a deep-rooted belief in divine calling, apparently resulting in a firm commitment to their educational setting. 
The significant impetus of calling appeared to motivate Christian educators to express themselves as individuals within the nurturing role of a teacher. The Christian school and home education milieu seems to provide for Christian educators abundant opportunity for this free exercise of religious conviction. One Christian educator reflected, "Since my faith was such a huge part in my own life, I really felt that if the spiritual aspect of a child's development was not recognized in the educational process, I then they would not be able to touch that part of me...It would be so confining.” Another Christian school educator echoed these sentiments, "I think that if I now would have to teach in a public school setting, it would be practically impossible for me. I would not be able to do that because my heart would be for the students to know the truth and I would want to openly speak that truth to them whenever the opportunity presented itself.” The ability to present personal faith and bring one's Christian walk into every aspect of the educational process seemed a major attributor to the commitment and calling felt by Christian educators in this study.

The second item that was similarly represented in the interview data was the recognition of personal gifting and special equipping. One interviewee said, "I guess I am continuing to be involved in Christian education because I believe that God has called me here and that I possess unique gifts in the area of education and instruction.” Another Christian educator said, "I believe that I am to use my gifting as an educator to serve His [God's] people.” Home educators also consistently demonstrated in their response to interview questions the recognition of God's direction and special equipping in allowing them the vision and wherewithal to successfully home educate their children. 


\section{Importance of Character Education}

The second similarity between groups identified in this study was the perception of the great importance of character education. The majority of responses collected in this qualitative study rated character education as “equal to" or "just as important” as the acquisition of academic knowledge. All recognized the validity of character education, yet some rated it even higher than academic objectives in the educational process. Common responses included, "Character development is a huge part of Christian education" and "I see character education as very important in any form of schooling." Others, especially those representatives of the home educating community, rated character education as "the ultimate purpose” and "highest goal.” One home schooling educator stated:

To me, character development/character education is number one, even way above the academics. Developing good character and righteousness in a child through discipline and the communication of virtue is much more important than any head knowledge.

Other home educators stressed the importance of character education with phrases such as “Character education is paramount” and "extremely important.” This high view of the importance of character education by Christian educators is significant as one explores the educational goals of both Christian schools and home educators as expressed in the findings of this study.

Christian school educators, although recognizing the importance of character education, were more hesitant to declare it as the primary goal. One experienced teacher honestly remarked, "I think it is one of our primary purposes as a school. When I first started teaching however, character education was not my primary focus. I was much 
more concerned with high academic standards. But as I have continued, I realize that character formation has now become central, in my own mind, as the ultimate purpose of Christian education.” The spiritual foundation and the desire to cultivate character in students is also a significant feature of the importance of character development for Christian educators. One teacher affirmed:

One of the primary goals in Christian education is to lead the students to a saving knowledge of the God who loves them, who has a plan for their lives, and who desires to have a close personal relationship with them. When that relationship is in place, no matter what the maturity level, the next step is to walk out that salvation and become more like Christ - which is character development.

The evidence of the conviction of the high importance of character education through the results of this study indicate the centrality of the issue.

Many responses from home school interviews indicated that the number one reason that they chose to home educate was character related concerns. These interviewees stressed the importance of spiritual formation as the ultimate goal in their educational program. The home educating interviewee who stated, "I think academics are simply a means to an end, but to teach character development and spiritual formation is our ultimate goal,” captures the essence of the shared goal of home educating parents. Their apparent ambition is certainly to build students of character, but more importantly, they wish to formulate the character of Christ in the students through the encouragement of a personal relationship with God. The Christian home educators interviewed in the study consistently held that the highest goal in home educating their children was to produce a godly heritage. They desire that their children would walk closely with the Lord. This spiritual aim is apparent in the expression of their educational views: "I consider my foremost education goal is character development in my children. I want 
them to know that character is who you are rather than what you know.” Another interviewee stated, “Character formation is central to our goals. The main reason I have chosen to home educate our children is to pass on the faith that we value so highly.”

\section{Character Education Defined by Milieu}

Because Christian education is diametrically dissimilar to its secular counterpart, the researcher was interested in ascertaining the emergent definitions and overall conceptual parameters of character education within the Christian school and home education milieu. A foundational dependence upon Biblical authority as a similarity between groups was made very obvious to the researcher throughout the qualitative data. The commitment to a higher standard within these two groups is obvious as expressed by one administrator interviewed, "If we are producing the mean average of character for today’s teenager, we are failing miserably because the bar is so low.” An overall commonality of this higher standard, which surfaced among those interviewed, was a resolute dependence upon the authority of the Bible. One Christian school educator stated, "We take our cues from the Bible as far as what character looks like," and several of those interviewed identified character development as simply "growth in Christ."

This dependence upon the teachings and doctrine of Christianity when defining terms in character education is significant, if not predictable. Consequential to the fact that the basis for Christian education is the Biblical standard, this is a significant aspect of the examination of character education in this context. One of the main reasons that we have different types of education systems in this country, as theorized by the researcher as a result of this study, is because they reflect the values that certain people hold. 
According to the data presented in this research study, these educators have identified certain things that are essential to the building of concept of "the whole man." Character seems to weigh heavily in that equation. The emergent consistency of the research data would indicate that a personal faith is the basis for moral principles and thus impacts the ideological factors present in the respective character education structures examined in this study.

The word character can be a vague term. Based upon the responses documented by the researcher, the individuals interviewed in this study considered character to be "the real you at home" or "the ability for the internal person to be outwardly reflected." This concept was captured by one interviewee who stated, "character is not something for rote memory, rather it is comprised of the fundamentals of living life in a godly way, moment-by-moment, day-by-day, whether you feel like it or not.” One Christian school educator stated:

We are trying to teach them how to be responsible, how to love what is good. We want to build into these children so that they can be the future leaders and gospel carriers. It is a huge thing that we are attempting to do with God's help.

Based upon this definition, character education is intended to permeate all avenues of life and learning and in the Christian school; setting is understood and measured by continuity in behavior.

The definitions of character development from the home educating group of interviews differed slightly from those of the Christian school educators. One interviewee clearly stated her understanding of character education, "My understanding of character education is based on the concept of the combination of two factors: first, the 
Biblical basis of character development, and second, the importance of familial interactions.” Another stated, "My goal in home educating my children included character training and family unity. I could never have built the kind of family unity and family identity that we have enjoyed if they went to school all day.” This emphasis of character development within the family structure appears to be a significant aspect of the defining of the home educator's concept of character education as yielded to Biblical authority.

\section{Foundational Philosophy}

The final similarity and apparent parallel between groups, identified in this study, is based on the shared philosophy of education as expressed by the choice of both Christian school and home education participants to educate Christian youth in a separate moral community. This concept is based upon the Biblical assumption that the parents are primarily responsible for the training and well being of their child. A complex philosophical perspective was formulated by the researcher in response to the views expressed by the qualitative data gathered by personal interviews of fifty-two Christian educators and is specifically related to character education. The emergent philosophy of character education incorporates definitive parental authority with the concepts of the whole-man approach to education, an explicit spiritual emphasis, Christian worldview training, the need for an educational environment conducive to character training, and the necessity of individualized instruction.

According to the results of the research data, most basic to the philosophical understanding of the motivation of parents and educators involved in the Christian school 
and home education milieu is the recognition of parental responsibly and authority in a child's education. One home school interviewee aptly described this type of parental approach to the educational process as, "Intensely involved in the direction of the education of my children.” Another parent/teacher testified:

Deuteronomy chapter six seized me and impressed upon me the duty I had been given by God as a parent to train up my children in all matters of life, during all stages of life, at all times of our daily life together. There was no room for 'quality time' vs. 'quantity time,' which was the major opposing argument. There was no place for choosing 'the best day care then available.' Rather, I suddenly saw my children as the most precious blessings on loan to me from God Himself, and that I was entrusted and empowered to raise my children for Him. Having acted upon the conviction to raise my children to the fullest extent as I had been enabled by God, I have never turned back.

The sacrifice of time and resources then is changed to be viewed in a different light as these parents fully accept the responsibility and resulting requirements of a uniquely Christian education for their children. The practical application of this acceptance is illustrated by parents who fund a private education or commit themselves to home educate. One Christian school educator and mother of two best expressed this understanding when she said, “As a parent, I am involved in Christian education because I believe that God has given us a mandate in training our children in God's ways and I saw the Christian Schools as a way of adding to what we were doing as a family.”

A second aspect of this philosophical understanding of the basis for character education, indicative of the findings of the research study, identified the concept of the whole-man approach to education as a significant attributor of the motivation for character education within the Christian school and home education milieu. As a part of this whole-man approach to education which includes physical, spiritual, intellectual, emotional, and social well being, the imposing of codes of conduct and high expectations 
both academically and behaviorally were one way in which educators indicated that they purposed to build character. Thus, it was stated:

We do have a high expectation. I think that is what parents desire us to have. Our high standards are reflective of what they are trying to formulate in their child at home and why they are sending them to a Christian school. We have high expectations academically and spiritually, so therefore our character development expectations are also very high.

These high standards are not the only means of acquiring a whole-man education. The expressed viewpoints of those interviewed in the study indicate that the acquisition of knowledge is considered useless without the wisdom, or character, to apply knowledge. This perspective is reflected by one individual who stated, "I am involved in Christian education because I do not believe that a child can learn without the framework of morals and Christian values and the knowledge that there is someone greater than you are.”

The spiritual emphasis present in all aspects of character development within the Christian schools and home education milieu, as reflected in this study, indicate a close relationship between the means of character development and that of spiritual growth. Because moral development and spiritual formation are irrevocably tied together in the perception of the Christian educator, the evaluation of character is also affected. One interviewee even stated, "Character development is, in my estimation, a spiritual goal and not necessarily an educational goal. However, it does cross over.” Because of the Christian undertones of all aspects of an education within the context of Christian schooling and home education within a Christian family, it is not surprising that character training is also dependent on the accompanying goal of Christian growth as expressed in the many times in the research interviews. The close tie of character development to spiritual formation was a very obvious similarity between groups in this study. Another 
of those interviewed expressed it this way, "The spiritual aspect is really the bottom line in character development, since without it anyone can be subject to the overwhelming situations or circumstances in life.”

Another unique aspect of this philosophy of character education measured within the Christian school and home education community was a commitment to foster a Christian worldview. One educator stated, "The Bible is the center of our character education and thus translates into all subject matter.” Those choosing Christian school or home education as the setting for their child's education seemed keenly aware of the difference in philosophy prevalent in the public schools. This was expressed in a number of ways: "I became very aware of things that were being taught in the schools that did not really line up with the way I view the world.” Another stressed the importance of a Christian perspective in education: “I knew I didn’t want my kids in a public school. I didn't want them in that type of setting- in terms of the values that would or would not be taught. I wanted to make sure that they were educated from a Christian perspective.”

This "Christian perspective" also defines the reasons behind right choices for students: "Character development is different in the Christian School because the in the public schools, all the kids are told is ‘be good,' 'just say no,' or 'just make good choices.' We have the advantage in the Christian Schools to have the Holy Spirit to do the work in the kid's hearts and lives.” Because Christian students have a foundation of moral truth and absolutes, character education within this context has the advantage of clarity within set boundaries. This desire for a cohesive moral and philosophical 
educational environment was strongly represented by the qualitative data gathered by the researcher.

The next commonality shared by the views of both groups of educators pointed out that school climate and the learning environment were important components in character education. One Christian educator remarked, “The Christian School environment is so wonderful in which to teach, since you can really teach without dealing with the behavioral issues as much as in the public schools.” Another educator reflected:

As far as character development, there is a tremendous climate for growth in an atmosphere of peace- there is not anxiety of students to fit in. There are also wonderful role models that present the character of Christ to my children moment-by-moment during the whole course of the day.

The need for quality teachers and adult/peer role-models was a common response in reference to the philosophy from which Christian educators and home schooling parents operated. One stated, "We desired that their heroes would not be the typical M-TV personalities, instead we wanted our children's heroes to be those who loved God, served the Lord, and had good character.”

One individual from the home educating sample base developed this desire for godly influences and role models in the educational process by taking it one step further to only include the immediate family and select friends: "We always wanted to surround our kids with others, other families who were modeling the same type of character and virtue that we were trying to build into them.” Another home education interviewee shared the advise, "Even what you lack [with this type of education], in perspective, will 
be far more valuable if you shelter your children from all the filth they would have to deal with in a peer group.”

The final aspect of the philosophic basis for Christian schooling and home education in reference to character education was the similar recognition as to the importance of the individual approach when developing a student's character. This conception stemmed from either the negative experience of parents in the public education system who felt like "one of a huge number" or of teachers who had previously taught in the public schools and were determined to fund a private education for their own children. Many home educators reflected the reasoning that they believed "we could do it better.” It seemed the consensus of those interviewed that the Christian school and home education milieu was able to offer an individualized education that cared for all aspects of the development of their students.

\section{Significance of Educational Structure in Character Development}

The discussion of the differences between Christian school and home education in terms of character training must begin by addressing the divergent structures presented by these educational options. The philosophy of moral separation within the educational process is applied very differently by the Christian school and home education milieu. One of the more significant findings of this comparative research analysis is the determination that the unique features of the educational structure and setting of both Christian school and home education do indeed lend themselves inherently to the success of programs of character development. 
Two distinct structural approaches to character development were substantiated by the analysis of the comparative qualitative data gathered by the researcher and were consequently labeled and investigated. The first structure to be identified as belonging to the Christian school model was designated, The Intentional Community. The second emergent structure in which character education was implemented within the home education model was termed, The Family Defined Culture. Therefore, the examination of the concept of a separate moral community in which to cultivate character, coupled with spiritual formation, revealed a delineation of two distinct modus operandi for character development distinctive of their respective milieu.

\section{The Intentional Community}

The Christian school milieu, as described by those interviewed in this study, was termed, The Intentional Community by the researcher in that it offers parents a unique culture of Christian educators and peers in which a child can develop spiritually and emotionally uninhibited. This is contrasted with the alternative of defensive parenting many families that send their children to public schools practice. One interviewee reflected, "When a child has peers that are not of like character then you have to deprogram those negative influences as well as attempt to influence that child towards good, godly character. It is obviously a lot harder to do.” The essence of this Intentional Community is to alleviate much of the moral confusion and present the student with a context of moral peers and Christian educators.

The community built in a local Christian school is intentional in that it is restricted to those individuals who agree with the mission statement of the school as 
defined by the school board and administration. Christian education in this context, as is reflected by the Christian schools profiled for this study, is an expensive endeavor: including a substantial amount of tuition and transportation expenses. It also necessitates the parents not only to invest their finances, but also their time and resources. Duties and responsibilities for the parents, as well as the students, are defined by code of conducts and academic standards set forth by the school. All schools included in the qualitative study required a signed family agreement as part of the admission process. The result is a contractual relationship between school and family in order to insure a commonality of educational objectives and continuity to the standards enforced in the life of the student. One Christian educator remarked, "The kind of education that we want to achieve for our students is not going to work if the three areas of the church, the home and the school do not all work together." Another teacher commented, "The freedom and support that we have in Christian education to build character into our students is very refreshing in today's culture. It is really the mercy of God that we can have such a thing as Christian education. We can practice the presence of the Lord with our students.”

This intentional community is most evident when considering the role models provided to students on a daily basis in Christian schools. The common adage that character and morals are not necessarily taught as much as they are caught was strongly reflected in the interviews. Within the teaching staff, Christian schools provide influential role models for their students. This tremendous character-building component to a Christian school education is described by one teacher, "No matter what subject matter that I teach I am always making sure that I am presenting things from God's perspective. For me, a Biblical worldview encompasses the whole man and therefore it is 
not just a discussion about God, but it is inspiring the kids to have their own friendship with God. Once you can get your personal friendship with God established then the character development follows naturally.” Others that were interviewed in the study credited the effectiveness of their character education programs to the quality of coaches, teachers, and parents that the Lord had assembled in the school. Central to this Intentional Community therefore is the Christian teachers who serve as living curriculum and role models that integrate Biblical truth into daily lessons.

Peer influence was another related tenet of the culture of character that takes shape at a Christian school. Christian schools are perceived as enrolling those students who are serious about their walk with Christ and can perform under high academic requirements. One teacher also commented, "It is so wonderful to teach in the Christian school environment since you can really teach without dealing with the behavior issues as much as in the public school.” The diminution of behavioral concerns and the ability of a Christian school to limit and control the enrollment of the school is one of the ways in which this intentional community builds the environment conducive to character development through mimetic desire:

The school does not turn people away solely based on their behavior, however, you can be removed if your behavior does not improve and is causing problems. That is one of the luxuries of Christian schools. I do not want to say that we are 'elitists,' that sounds very rigid, but we do not have to take everyone like a public school does.

Things such as codes of conduct, limited enrollment, enforced disciplinary measures, and high parental involvement make Christian education a very appealing option for Christian families interested in the character development and discipline of their children. 
Although Christian schools are institutional places of learning, small class sizes, family accountability and involvement, as well as committed teachers and staff make for a very successful context in which character education can flourish. One educator said, "Character development needs to be addressed on an individual basis. You need to meet the kids and address issues where they are and talk about what they are experiencing. The personal approach is essential.” Each Christian school defines for itself the standard of the community it seeks to embrace. These standards are somewhat unique to each individual school as it reflects the moral culture that it serves. One educator observed, "What is important for character is different depending on the culture. Character development in the Christian context, still varies depending on the background of the people who are making the decisions.” For Christian families who wish to enroll their son or daughter in one of the four target Christian schools included in this study, they must first review the statement of faith and sign a family agreement. These documents insure that the contractual relationship between family and school will be a profitable one, based on common goals for the student. By signing this family agreement, the parents acknowledge their willingness to align themselves with the vision and purpose of the Christian school.

\section{The Family Defined Culture}

The home education milieu can be defined as a uniquely constructed culture in which the family is the primary organism which fosters character development. This milieu is therefore described by the researcher as The Family Defined Culture in that it attempts to shepherd a child's development solely within the context of the perimeters

determined by the family. This concept was expressed by many home educators 
interviewed in the study: "In this culture, things are so broken down morally, that we tried to create our own culture by selecting carefully our family's circle of friends that we associate with.” Another interviewee stated, "By means of home education, we wanted to have total control over the influences and education of our children.” The essence of this concept of a Family Defined Culture was encapsulated by one home schooling parent who said, "Our standard does not come from the culture around us." Home educating families, therefore, choose to create this Family Defined Culture to disseminate the instruction of character development and spiritual formation in a protective environment and under a set of controlled variables.

Because of the educational structure of home education, the means of informal character training are limitless. One home educating mother states, "There is always time for character development in home school and I love that about this educational format.” Another home educating parent affirms the importance of the home education structure in the character development of her students:

I love being with my children. Even now with three teenagers, I still really enjoy being with them. This was an essential part of building a working relationship with them. You cannot predict when a child will need to work something out with you or when they just need to talk to you. I find that with my teenagers, when they want to talk, you better be available to listen because they do not always want to talk things out. As a home school mom, I have that freedom to be available to my children.

This parental constant in the character development process was viewed as very beneficial by those interviewed in the study. One interviewee said, "One of the most specific things that we have done as parents to produce character in our children is to home educate them." She went on to explain: "Because of the format of home education, we are on top of any character issues that are surfacing as the child grows, develops, and 
changes. I believe home education is a great venue to help a child grow in the area of character.” The inherent structure of home education, again and again, was referred to as a successful means of informal character training.

Another unique aspect of home education that aids the development of character and the process of character formation is that the parents' witness, and in fact direct, every facet of the life for the child; whether it is their studies, their playmates, work experiences, familial interaction, etc... There is an emphasis of interaction within the home which is considered the most fruitful time of training and growth in the area of character, especially at young ages. Just as a separate moral community is built in the Christian school, home educating families are attempting to create their own by limiting harmful influences and encouraging constructive educational experiences. This Family Defined Culture is therefore solely dependent on parental involvement and thus has distinctive features. The uniqueness of this structuring is that it is directly focused on the needs of the individual, even in areas of character development:

The concept of character education has been crucial in our decision to home school. We felt that in a home schooling setting, we would be able to spot problems at their very inception and zoom in on them. We can address problems quickly, instead of hearing about it from a teacher or maybe not even being aware of the problem.

One such advantage to constant parental involvement, as pointed out by a home educator interviewed in the study, relates to the consistency of discipline, "We have the advantage of being the parents and we can discipline the children as we see fit whereas the teacher is very limited in the amount of discipline he/she can use.” Beyond teaching and discipline, the home educator strives to examine and discern the various individual issues of the student with the intent to bring immediate resolution. The parental presence in 
home education is therefore advantageous to character formation. One home educator observed, "I just think it is impossible to address some of the heart issues in a traditional classroom setting. It was not just classroom control that I wanted for my child; we were able to go deeper.” Through the home education model, things such as personality, special interests, learning style, family heritage, and spiritual maturity appeared to be dealt with in a very individualized way. Moreover, the time together also creates, as one interviewee expressed, an "intensity of relationships" which necessitates character development.

\section{Character Traits Emphasized}

In further examination of the differences between the Christian school and home education milieu, the researcher found significant divergence in regard to what character traits were emphasized. The top five character qualities in the interview response of both sets of educators were gathered and analyzed in relation to their respective educational setting. The results were somewhat surprising. The Christian school setting focused their character development on those external qualities necessary to meet the behavioral objectives of the school. These included in order of importance: honesty, responsibility, diligence, respect, and fairness. Conversely, the home education educators reported an emphasis on more internal character qualities, such as obedience, integrity, perseverance, teachable spirit, and initiative. The resulting comparison provided a view of the difference in approach to character education in this study between groups.

The target Christian schools included in the research base emphasized the behaviorally tied external character traits. This is logical since character evaluation tends 
to be very behaviorally driven in the institutional setting. In viewing the emergent top five character qualities described by this group, which included honesty, responsibility, diligence, respect, and fairness, one can see a definite parallel between the schools behavioral standards and the resulting character emphasis. Qualities such as honesty and respect are very closely aligned to classroom management. The other character qualities including diligence, responsibility, and fairness can also be behaviorally measured within an educational setting. Thus, character education within the four target schools included in the study tended to emphasize character qualities that were externally expressed.

The response of home educators, in reference to the character qualities emphasized, resulted in a surprising contrast to those qualities accentuated in the Christian school. The top five character qualities to emerge from the qualitative data of the home school representatives in the study were obedience, integrity, perseverance, teachable spirit, and initiative. These character qualities address more internal attitudes and heart issues. The deeply personal approach to character training of the home educating representatives of this study indicates a profound emphasis on individual selfgovernance. The qualities of obedience and teachable spirit indicate willingness to work on character and the importance of proper response to further growth and correction. Perseverance and initiative are reflective of the attitudes necessary for personal advancement in an individualized educational program. The emphasized character quality of integrity mirrors the strength of character education within the home education milieu, since character development is deeply personal and focused on the internal, heart issues. This type of character training builds a strong sense of personal integrity and ownership. 


\section{Models Implemented in Christian School}

Of keen interest to many teachers in Christian education is how to go about the practical implementation of character education in the classroom. The plethora of teaching models proposed in the adaptation of character education within the classroom can be very confusing. Thus, the researcher has taken great pains to research the various recommendations of Christian school educators of character education models that have proved successful. The categories of character education common practice as detected in the Christian schools by the researcher included formal Bible instruction, ministry and spiritual growth activities, the cultivation of a safe learning atmosphere, sports, disciplinary measures, character recognition through awards, models of open dialogue, and awarded special responsibilities. The major components of training by which character was presented in the Christian school milieu included practical training, units or workshops, modeling and mentoring, supervisory follow-up, consistent disciplinary actions, and religious instruction. The following is a brief survey of the elements involved in the character education programs of the four target private Christian schools included in the study.

Character instruction was strongly integrated in the formal Bible instruction provided by the schools. One administrator commented, "We have formal Bible instruction daily which I would consider to be the ultimate character education program.” The daily Bible reading, weekly chapels, and required Bible memorization was also indicated as instrumental in the character education program of the school. Along with the formal biblical instruction, the modeling of character by the teacher was commonly referred to as a "living curriculum" or "a consistent presentation of what it means to be a 
Christian." One educator said, "I think our very lives are a testimony to the type of character that we teach.” Therefore, the dependence on formal Bible instruction, the study of the Scripture through enriching spiritual activities, and the mentoring position of modeling character, proved the primary means of character education as reported in this study.

The second category of importance in regard to character education and character development within the Christian school milieu was ministry and spiritual growth activities. This included daily prayer times, chapel services, special speakers, and ministry opportunities. Community service days were a favorite in addition to choir ministry tours, nursing home visits, Faith in Action classes, and missions trips. One Christian school educator said, "I think it is wonderful to be able to focus students on a task in which they can apply what we are trying to teach them. It is a great opportunity to practice good character.” Another educator stated, "Sometimes you have to put tasks to specific character traits in order for the students to grasp to concept.” The opportunities to put "feet to their faith," as one educator put it, seemed to be a valuable component of many of the character building initiatives within the four target schools.

A third factor in the practical models of character development within the Christian schools was a cultivated, learning environment with an atmosphere of peace and order. This is achieved by clear boundaries in discipline. One educator remarked, "I think the discipline that is maintained at our school provides the foundation for these kids to move forward in their character development." Another staff member said, "We want to create an atmosphere here that encourages good character and in fact requires it.” The 
continuity also between home and school was part of building this safe atmosphere of learning: "We support what our parents are attempting to do at home." The small, nurturing atmosphere of the Christian school is very attractive to parents because of the atmosphere of safety and care it provides.

A fourth compliment to the character education programs implemented at the schools profiled in the study was the sports program and other special interest course offerings. A tremendous platform of character instruction is team sports. One teacher observed:

I hear our coaches emphasizing character on the court, off the court, in their team prayer times, with pep talks, and sportsmanship. Sports is an area that can bring out the worst in people and that is why it is a key place where character is emphasized in our school.

Apart from the high interest avenue of sports, it was reported that upper level students are very interested in classes such as current events, evangelism, and ethics course offerings. Spiritual retreats and guy/girl break off groups or C.A.R.E. groups also proved a successful means of engaging the students in the formation of character through open dialogue. One teacher said, in reference to such offerings, "The reality of the Christian life is probably the most effective formal character training that occurs here at the school since they are actually talking about themselves and their own struggles, feelings, and perspectives.”

The final grouping of successful character education models, practiced in the Christian schools, as surveyed by the researcher included the recognition of character development through awards, character progress reports, and the awarding of special 
responsibilities to those showing good character. In the area of awards of recognition, the researcher found abundant examples. Three most memorable were the B.U.G.S. awards, the Principal Awards, and Timothy Award. The B.U.G.S. awards were described by the administrator of one school:

We have weekly chapel awards that are called B.U.G.S. I got this idea from ACSI. B.U.G.S. stands for 'Becoming Useful Godly Servants.' Each of the teachers gives a B.U.G.S. report to the principle weekly of any student that they have noticed demonstrating outstanding character. We give these awards out at chapel and the kids can hardly wait. They are just little certificates with bug stickers, but they really like being recognized in front of their peers for things besides just academic achievement. These kids are being recognized as useful godly servants and they love it!

The Principal Award was somewhat similar. Each week an award was given by the Principal to a member of each class. These awards named a character trait that was seen demonstrated by that student in the past week. The Timothy award was an award in diligence and perseverance. Several of these named character awards were given at the school and each were representative of a study in the life of that Bible personality. Instead of awarding “top of the class” or "top student” awards, the Timothy Award represented a high level of diligence scholastically, but also was in the context of character. Awards and recognition of character can be a very positive thing it done correctly: "We look to honor those who are servants, encouragers, and those who are very diligent.” All four of the target schools of the study also held a character awards assembly at the end of the year where each of the students received an individualized character award.

Character progress reports and the awarding of special responsibilities to those showing good character were also very positive reinforcement tools of character 
development as reported by those interviewed in the study. The researcher was surprised to find that each of the target schools included in the research base had a character assessment section on their report card. Besides this means of reporting character development to parents, the schools also had "commendation reports" or "praise reports" that were sent home periodically. Special responsibilities were given to older students based upon character observed. Safety patrols, ministry teams, teacher aids, and kindergarten buddies, were just some of the positions of responsibility and prestige offered to those of exceptional character. Classes were also called on to prepare chapel presentations or lead worship. The senior class was used by one Christian school to host a special event for the entire school. This recognition of character helped to produce, according to those interviewed, a culture of positive peer influence.

\section{Models Implemented in Home Education}

The home education teaching models as applied to character education were mostly unique to this educational structure. The primary means of character education applied within this milieu was the concept of modeling and family unity. One home educator said, "I think that home schooling provides a unique opportunity for character development since we are all together so much of the time.” Parents are acknowledged as the primary role model in the child's moral development. This is expressed by one home school parent who said, "I have found that I have to be portraying the character that I wish my children to emulate. When there are issues that need to be addressed, we are able to address them immediately and individually.” The model of family when dealing with the issues related to character development is a natural structure inherent to character growth: "There is a lot of interaction just within our home and that seems to be 
the most fruitful time of training and growth in the area of character, it is the whole purpose of family life.” The constant familial interaction which characterizes a home educating family is recognized by those interviewed by the researcher as a primary means of character development.

The home educating families included in the study were very eager to acknowledge their dependence of Biblical authority in the moral education of their children. "Family worship" and "family devotions" were considered part of their character training. Complete integration of Biblical truth into the curriculum standards was a given. The reading and memorizing of Scripture, comparable to the Christian school, was implemented. Apart from this, personal journaling and life notebooks were also implemented as a self-tracking mechanism for students to monitor their character development. These "life notebooks" or as some called them "character notebooks" were made to have a section on each character trait that came up in the course of personal character growth. These were typically areas of weakness in which the student made an independent study on the character trait. One home educator explained:

I would make the child aware of the character weakness. I would name it for them and explain it. I would then use Scripture to correct it. Then every time that particular character flaw is expressed in the child's behavior, I can refer back to that defining lesson and show him how the character trait is manifesting itself again, thereby allowing constant feedback to that initial lesson.

Each character trait was accompanied by it definition, scriptural examples, real life illustrations of what the character trait is and what it is not, stories that involved the character trait, and personal experiences related to the character trait. 
The next category relating to the means of character development within the home education milieu as described by the research sampling is the purposeful imposition of preventative measures and positive socialization. The practice of home education provides the time and necessary sheltering to influence a child's character development in the fullest sense. One home educator states:

Parents need to impart instruction to their children. But how are you going to impart those truths if you do not spend time with them? Therefore, it does not make sense to me to send them away to spend the bulk of their day with a peer group that are themselves in character formation. The best people to learn from are the parents, godly adults, and extended family members. Not that I don't want my children to spend time with their peers, but the typical school day is lopsided, in my mind, for them to go away to school for the majority of their day.

Another mother said, "I am in touch much more so than a teacher would be as to what my children need to work on as far as character.” These home school parents encouraged godly friendship with like-minded students and also provided for godly adult interaction. In choosing the peer group of their children, these parents believe that they are mentoring and sheltering their children in preparation for their emergence as a godly influence. One parent expressed it this way:

I think one of the most important things we have done to produce character is expose our children to others who have good character in their lives. We want them to have examples of people that reflect the Lord clearly. It was important for us to help the see and identify godly character.

An example of the one of the preventative measures home school families took to avoid undue influences in their child's life was the removal of the television from the home.

The phrase "father knows best" is descriptive of the concept of parental guidance in the home education structure. A home educator stated, "I believe that home schooling is a great way, indeed the only way for our family, to be on top of character formation.” 
The idea that as more time is spent by the parent with a child, the more influenced that child will become by the parent's values is reflected by another home school mom who said, “A teacher who only has them for one year will not know the character struggles of a child as fully as a parent does.” The teachable moments and informal character training that takes place during the course of the day between parent and child in home education is truly one of the strengths of this format of character education. One educator stated it this way: "Home education provides us as parents more of an opportunity to develop character in our children.”

One of the unique methods of character development emergent from the home education qualitative data gathered by the researcher indicated that literary selections were a significant media of character training. Since home educated students tend to be more avid readers (Ray, 1997) then their public and private school counterparts, the inclusion of biographies of great men and women of the faith and heroes in history was a way in which character education was imparted: through the student's reading selections. Literature provided for many of the home school families included in the research a magnificent opportunity for enjoyable character development.

The final avenue in which the researcher found significant attention was paid by those interviewed was that of service and family projects. Service was one aspect of character development that was recognized for its importance. It was represented as essential that Christian youth not only have the head knowledge, but also use that character in practical ways of service and compassion. Opportunities for service are viewed within the home educating community as the means of cementing the character 
traits in the hearts and minds of its students. The idea of building family unity, personal character development, and mutual teamwork was the objective of such service outreaches. Family projects reflect the importance of family unity within the context of home education: "I could have never built the kind of family identity that we have enjoyed if they [my children] went to school all day.” One family cited their family project as, "sponsoring two children in Asia.” Another family reflected on their life circumstances as a significant feature of their family’s character training: "We have been blessed in our family to have a severely disabled child and that has been a real tool the Lord has used to help develop compassion and gratefulness in our children.” According to those interviewed, such challenges in life embraced by the whole family have produced a unity and closeness that results in a greenhouse effect on character development within the family members.

\section{Evaluation of Character Education}

The means of evaluation of character is an important aspect to any discussion on the topic of character education. The magnitude of developing godly character and moral standards in the next generation of Christian families is universally recognized by the Christian community as an essential component of twentieth century parenting and Christian education. One Christian educator stated, "We are at such a critical point in our history, with families and marriages being attacked, it takes strength of character to stand up and make right choices and to be able to verbalize about why they are make those choices.” If the goal of character formation is such a central tenet of Christian education then it must be effectively evaluated since any educational goal must be measurable. However, as stated by an interviewee, "You cannot put a test in front of a child in order 
to measure character. It is mostly observable behavior.” What then are the most effective means of evaluation of character education? In the analysis of the qualitative data the researcher found significant deviation in the perspectives of evaluation between the Christian school and home education milieu.

The views of the Christian school educators included in the study pointed to the evaluation of character in relation to the standards or codes of conduct established by the school. This method of evaluation was very behaviorally driven and actions rather than attitudes served as the indicators of character. A section on the report cards devoted to character was present at all four of the target Christian schools. This fact shows a priority for character evaluation, yet the assessment tool was somewhat superfluous in ranking observable character. Categories included such things as neatness, effort, class participation, finishing assignments, etc... The overall effectiveness of this evaluation tool is suspect, since none of those interviewed in the study referred to this tracking tool as an aid of character development.

Contemporaneous to its counterpart in the home education setting, Christian school educators, in acknowledgement of Biblical authority, saw character education as a pursuit of spiritual maturity within the context of a personal relationship with Christ. One educator commented:

The unique thing about character education in the context of Christian education is that you can say to the student, 'What was your heart attitude?' or 'What would the Lord have said about that?' In that way, you can be very definitive. You do not have to skirt around the issue. 
The spiritual emphasis when evaluating character is somewhat problematic as expressed by another interviewee, "It is hard to measure character because the students can in a sense perform. Only the Lord sees their heart.” Other measures of evaluation dependent upon the spiritual application as recommended by the educators interviewed in the study included "seeing evidence of Spiritual fruit" and "looking for the character of Christ."

The somewhat idealistic character education evaluation based on spiritual formation was further supplemented by certain descriptors or indicators of character development in a student. The five primary indicators, as expressed by the qualitative data of the study, was a willing to serve others, the ability to converse with adults, the ability to take on a position of leadership, the demonstration of a good work ethic, and the readiness to take responsibility for one's actions. This emphasis on service within the research population as the first indicator of the development of character was best described by this illustration: "Like a muscle in training, character needs to be worked out so that it can grow and be strengthened.” The indicators as afore mentioned, unlike any assessment guidelines, were purposed to simply outline the kind of student that was considered to be ones who had "good character" by educators.

The home education milieu, in contrast to the means of assessment set forth by the Christian school educators, saw the evaluation of the development of character as primarily relationally based. The idea that character evaluation is dependent upon a close relationship between a mentor and a student was a step away from the behavioral mode of assessment characterized by the Christian school educators. In the home education model, even the smallest growth in character was recognized whether it was a decision 
that effected behavior, or whether it was just a change in attitude. One home educator observed: "The road signs that I have found as creditable evidence of character is that they would apply those principles when not enforced.” The concept of control beliefs that served as a guide for the individual evaluation of character within this milieu was unique to home education.

\section{Perspective Outcomes of Character Education}

The final comparison that the researcher was alerted to by the qualitative analysis of the interview data was the difference between two perspective outcomes of character education between the Christian school and home education milieu. The Christian school educators had a long-term view of the outcomes of character development. One such educator stated, "I think Christian character is something that you really are hard pressed to evaluate until the student is further down the road.” Conversely, within the home education milieu, a much more incremental approach was applied when determining the outcomes of character training. These home educating parents used terms such as “desires,” "relationships,” and "feelings” when describing their perspectives on the outcomes of character education. Statements such as, “They have a desire to walk closely with the Lord and serve Him with their lives” indicate a present state, whereas the Christian school educators were more inclined to present future accomplishments as an evidence of character.

The Christian school educators were consistent in describing the outcomes of their character development program in relation to years into the future. Character attainments such as “choosing good friends in college," "building a good marriage 
someday," and "raising their kids to love the Lord” were all expressed as futuristic forecasting of the resulting effect of character formation in the elementary and secondary years. One interviewee observed, “A lot of the 'evidence’ I see so clearly is demonstrated by our graduates in the choices that they make and the places they allow the Lord to take them in their future." Although the long-term perspective of effects of character training and the blessings of a life of character and virtue is one of the great benefits of character education, it was troubling that the Christian educators could not formulate more incremental outcomes within their specific programs of character education.

The home education research sampling expressed a different perspective on the immediate outcomes of character education. They viewed the results of character formation in a series of short-term goals accomplished through incremental growth. The two aspects of the groundwork of these short-term accomplishments appeared to the researcher to be relational accountability and involvement by the parents. One home educator said, "We have a strong relationship with our children, this is something I believe home schooling fosters, we have their hearts. Thus, when they obey us it is out of love.” One interviewee stated: "I believe what encourages me most in regards to character is that they [my children] are making attempts to do what they know is right.” The short-term progress is viewed as of the utmost importance. Even “attempts” were recognized and encouraged in this milieu as gradual progression of moral sustenance. Although the long-term benefits of character education are also recognized and embraced by home educators, "I feel that if my kids finish school loving the Lord and working toward putting Him first in their lives - taking on His character - then I have been 
successful," the focus on the immediate issues of character strengths and weaknesses of the individual was an apparent strength in home education's approach to character education.

\section{Summary}

The intent of the research project was to present a phenomenological perspective and comparative analysis of character education within the Christian school and home education milieu. The findings suggest that character education and the juxtaposition of that goal with the transference of faith is a major contributor to the obvious commitment and calling felt by those in both arenas. Although the purpose and intent of both sets of educators were in many instances similar, the researcher found six areas of significant deviations in the instructional models and application. These deviations in implementation led to an examination of the structures set forth in both Christian school and home education. The impact of the atmosphere of learning and the underlying Christian worldview, on character education, has its origin in foundational Christian philosophy. The strong, Biblical emphasis held by Christian educators in both milieus facilitates the practical and effective application of character training unique to Christian education. 


\section{CHAPTER V: Conclusions}

\section{Summary and Discussion}

As an outgrowth of a Christian educator's obedience to Christ and commitment to excellence in education, the concept of character development is held in high regard. Intrinsic to the Christian school and home education milieu is the desire to produce spiritual formation and character development in its students. The researcher has confirmed the overwhelming agreement among Christian school educators and home educating parents that character development is significant within the respective educational objectives of both forms of Christian education. The researcher was delighted with the resulting phenomenological perspectives gained by the qualitative research process of this study and anticipates its findings to be of use to others in the Christian education community.

The concept of character education struck a deep resonance with those interviewed in the research study. The author was surprised to find the overwhelming assertion that character education coupled with spiritual development was the number one reason for the educational choice among research interviewees. This high estimate of the importance of character education, indicative of the Christian worldview present in these educational settings, was reinforced by the acknowledgement of a foundational dependence upon Biblical authority. The further recognition of the findings of the researcher as to the perceived importance of the spiritual and social aspects of character education within the educational development of students reinforced the idea of educating Christian youth in a separate moral community. 
The high standard both academically and behaviorally in the Christian school is often what sets it apart from its equivalent in the pubic sector. The intentional community built within the local Christian school is reflective of the values of parents and Christian educators who invest themselves in providing this educational option for their students. Because of the intentionality of this form of costly, privatized education, the results are very positive in terms of character development. Ideally, the school serves Christian families as a continuation and complement of what it is they are already attempting to build into their children at home. Another benefit of this community, within the Christian school, is that it provides for students the opportunities for service and responsibility that most would agree are significant in terms of character formation.

Addressing heart issues may be beyond the scope of what a Christian school can do because of the number of students that they are responsible to educate and the inherent challenges in discerning and addressing individual character development in an institutional setting. However, because of the educational structure of home education, the means of informal character training are limitless. While home education may lend itself more freely to character training due to its unique setting and inherent sense of individualized learning, it also more readily lends itself to mentorship, discipleship, individualized learning, and strong family identity. The home education model provides a consistency in discipline recognized as indicative in the formation of character. The importance of the parental constant in character education is inherent in home education because within this model the parents take on the full responsibility of directly orchestrating the character formation and academic development of their children. 
In the book of Proverbs, it says, "Like a city whose walls are broken down is a man who lacks self-control” (Proverbs 25:28, NIV). The word picture of a city without walls indicates a complete yielding and total surrender to its enemies. It has no protection. In the same way, if we are not vigilant to throw up the walls of character and virtue around our students, then they will be at the mercy of whatever enemy that the world brings to them. The circumstances of life, the devastation of sin, and the lack of good character are all included in this enemy that is arrayed against us and our children. If character and virtue is not built up and strengthened, as a protective wall surrounds a city, then Christian students will have nothing with which to defend themselves when they leave the safe environment fostered by the Christian school and home education milieu to face the challenges and enticements of the world.

\section{Suggestions for Implementation}

Character education is irrevocably tied to spiritual growth. One would assume then that character development would permeate the Christian school curriculum and the religious cultural environment. It is the clear cut goal of both the Christian school and home education milieu of producing men and women of good character. My concern is that Christian schools, like many churches, are instead reflecting the general culture and educational trends of the day. Character education tends to be haphazard or hidden within the general curriculum. Conversely, the application of character training within a strictly formal setting leads one toward the establishment of external rules rather than addressing character as a heart issue. To accomplish the successful implementation of character education in the classroom there must be a concerted effort on the part of the 
teachers and a clear vision of the school's administrative objectives in which character development is elevated to a place of importance.

Within Christian education, the occurrence of character education is often assumed and, to some extent, the communication of virtue is indeed present since both the Christian school and home education milieu are designed in such a way as to maximize the modeling of Christian character and create a culture of accountability. However, the philosophy of the individual teachers and the school administration will profoundly influence the way in which character education is presented and therefore its overall effectiveness. The researcher would urge Christian schools to prioritize and systematically integrate character education. According to the results of the study, it does not necessarily naturally flow. Since character education is such a central tenant of Christian Education, Christian educators must purposefully make an effort to examine the ways in which character is developed.

For those educators specifically involved in home education, the necessity of parental intentionality to involve their children in the development of character and virtue is of the utmost importance. Just as a school's character education program must be codified within the school community by the administration and the efforts of individual teachers, the home educating parent has the unique opportunity to impress upon their student good character and to very personally identify the areas of weakness within the process of that child's character development. The ability of the student, with the guidance and accountability of the parent, to recognize the areas of character that need more work is a very powerful means of character development. Parents should address 
character issues in their child's life by first naming them and then helping their student to recognize them. In this way, they will be equipped to more readily recognize their lack of character and lay it aside.

As a Christian educator, the issue of character education is one step beyond the academics. It is important to maintain close interaction with parents when prayerfully setting individual goals for students. Frank discussion with parents in the beginning of the year as to what character issues their child is facing is highly recommended by the author. A parent survey has been developed (see Appendix I) as an outlet of the findings of this study on which the researcher invites parent feedback on the student's emotional and social development as well as areas of character weakness and academic struggles. This tool was designed in order to make a clear determination of the character goals, as well as the academic goals, to be accomplished with each student over the course of the year. The blessing of the Christian school and home education milieu is that educators have the desire to see their students as God sees them. Christian educators therefore desire the growth of character in each of their students.

\section{Recommendation for Future Research}

The aim of this study was to describe and gain more understanding of the common practice of character education in the Christian school and home education milieu. The author feels more research should be conducted in this area, especially in reference to the current Christian school and home education movement. In retrospect, the author would have done three things differently while conducting this qualitative study. These three additions to the research methodology are thus recommended by the 
author for those conducting future research on this topic. First, more emphasis should be placed on group discussions when incorporated in the interview process, because of the tremendous amount of time the individual interviews require. Second, it would be beneficial to conduct an in-depth survey of the character curriculum, both Christian and secular, and determine the difference in philosophy and implementation. The third recommendation made by the author is that more time be spent in the interviewee's specific classroom or home educating setting for the sake of observation. This would be beneficial in determining the amount of informal character training that takes place on a daily basis and would also provide a more detailed approach to the explicit means of character development utilized by educators.

The researcher is confident that she has conducted an exhaustive search of the research available and has, through in-depth interviews, sought to capture a phenomenological understanding of the issues involved in character training and spiritual formation as practiced in the Christian school and home education milieu. Yet, the research was restricted to the primary, middle, and high school years of a student's character training and consequently to the views of parents and educators within that period of educational development. More extensive research in this area is necessary. The author recommends more longitudinal approach in measuring the effectiveness of character education within the Christian school and home education milieu in the years after high school graduation. If one had the ability follow up the student's display of character when they leave the educational setting conducive to character formation, it would be interesting to see how many continue to function within the Biblical mandates of character. The results of such a study would be significant for educators in 
determining the true effectiveness of the years of character training invested. It would also be profitable to interview these Christian young adults in order to solicit their opinions of what kept them for Christ and how they confronted challenges in the years outside their protective educational environment.

The remarkable historical progression of the public education system’s return to character education within the last decade would be an area of research significant to the Christian understanding of this issue. The author would recommend for future research an inquiry into these current trends that are an obvious backlash of the failure of the situational ethics as previously taught in public schools. An examination as to the complete failure of the values clarification movement of the 1960s and 1970s would be a dramatic philosophical comparative survey to the Christian domain. The stark differences between the more radical early forms of character training and the recent return to character education in the public schools would also be a valid area of future study. For Christian educators, this move towards the Biblical ethic even though the system denies the foundation of character that they have adapted, is a curious irony. 


\author{
APPENDIX A \\ Sample Selection Criterion Checklist
}

\title{
CHRISTIAN SCHOOL EDUCATORS
}

Perspective interview subjects must meet all criterion standards in order to be eligible for selection. Check all that apply.

Interviewee must be a born-again, professing evangelical Christian active in a local fellowship.

Interviewee must have previously been active in a teaching position for a minimum of five consecutive years in a Christian school.

Interviewee must currently be teaching in a full-time administrative or teaching capacity.

Interviewee must be employed full-time by either 1) Bethel Christian Academy, 2) Christian Community School, 3) First Baptist Christian School, or 4) Open Door Christian Academy.

\section{HOME-SCHOOL EDUCATORS}

Perspective interview subjects must meet all criterion standards in order to be eligible for selection. Check all that apply.

Interviewee must be a born-again, evangelical Christian active in a local fellowship.

Interviewee must have previously home educated for a minimum of five consecutive years in the state of Ohio.

Interviewee must currently be home educating one or more students.

Interviewee must be active in area home school support group.

Home educating family must have long-term commitment to home educate through high school.

All school aged children, currently in the home, must be home educated. 


\section{APPENDIX B}

Subject Interview Release Form

\section{Interview Release Form}

By signing the form below, you give your permission for any tapes made during this interview to be used by researchers and the public for educational purposes including publications, exhibitions, World Wide Web, and presentations.

I, having been interviewed by

GRETCHEN WILHELM, hereby grant GRETCHEN WILHELM permission to record my voice in an interview and grant her permission to include quotations from said interview in a Master's degree thesis she is preparing for publication through Cedarville University.

I hereby waive any fee or other compensation from GRETCHEN WILEHLM or from CEDARVILLE UNIVERSITY for the use of quotation as aforesaid or in any republication, reprint, transcription, electronic medium, or recording of the article containing said quotations.

Interviewee's Printed Name

Interviewee’s Signature

Date 
APPENDIX C

Subject Profile Form \& Field Notes 


\section{Subject Profile}

* Interview Number:

Code:

* Interview Type

$\begin{array}{cc}\bigcirc & \bigcirc \\ \text { Christian School } & \text { Home School }\end{array}$

Subject Title

$\begin{array}{ccc}\bigcirc & \bigcirc & \bigcirc \\ \text { Administrator } & \text { Parent } & \text { Teacher }\end{array}$

Years of Teaching Experience

$\begin{array}{ccccc}\bigcirc & \bigcirc & \bigcirc & \bigcirc & \bigcirc \\ 5 & 6 & 7 & 8 & 9 \text { or more }\end{array}$

Educational Level

O $O \quad O \quad O \quad 0$

High School BA Other Master's Ph. D

* Number of Children in School

$\begin{array}{ccccc} & \bigcirc & \bigcirc & \bigcirc & \bigcirc \\ 1 & 2 & 3 & 4 & 5 \text { or more }\end{array}$

* Instruction Grade Range
O Grade K-3
O Grade 4-6
- Grade 7-8
○ Grade 9-12

* Family Structure

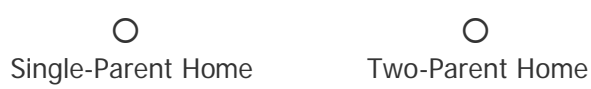

Ethnicity

- White-Caucasian

O Hispanic

- African-American

Other

\section{Additional Comments and Reflections}

Interview Date: Time:

\section{Field Notes}

* Question One.

- Question Two

Question Three

- Question Four

- Question Five

- Question Six

Question Seven

Question Eight 


\section{APPENDIX D}

Christian School Interview Tool 


\section{Cedarville University}

\section{Christian School Interview}

Conducted 2004 by Gretchen Wilhelm

Question One

Why are you involved in Christian education?

Question Two

How have you come to understand the concept of character education in this context?

Question Three

How is character development integrated at your school?

Question Four

What model does the school implement to encourage the development of character?

Is it formal or informal?

Question Five

What does the school actually do to produce character in the students?

Question Six

What is the school's expectation of the student in regard to character?

Question Seven

What evidence in terms of outcomes demonstrates that you have successfully cultivated character?

\section{Question Eight}

Is there anything else that you would like to discuss or would recommend I ask in future interviews? 


\section{APPENDIX E}

Home Education Interview Tool 


\section{Cedarville University}

\section{Home School Interview}

Conducted 2004 by Gretchen Wilhelm

\section{Question One}

Why have you chosen to home educate your children?

\section{Question Two}

How have you come to understand the concept of character education in this context?

\section{Question Three}

How is character development integrated in your curriculum and educational goals?

\section{Question Four}

What do you do to encourage the development of character? Is it formal or informal?

\section{Question Five}

What specifically do you do to produce character in your children?

\section{Question Six}

What is your expectation of your child in regard to character?

\section{Question Seven}

What evidence in terms of outcomes demonstrates that you have successfully cultivated character?

\section{Question Eight}

Is there anything else that you would like to discuss or would recommend I ask in future interviews? 


\section{APPENDIX F}

Project Explanation and Formal Request for School Staff Participation

Dear Teachers and Administration,

I would be very grateful to you if you would allow me to include your views in my research for my Master's Degree thesis. The interview is approximately 20 minutes in length and I would need to set up an appointment with you after school ASAP. I have attached a copy of the eight questions that I will ask in the course of the interview and have also included a copy of the release form that you would be asked to sign. The main criterion of my research base is that the interviewee must have a minimum of five years of experience teaching in the realm of Christian Education. I will be interviewing teachers from other area Christian Schools including Christian Community, Open Door, Bethel Christian, and Elyria Baptist. Thank you for your consideration.

I would greatly appreciate your assistance in my research.

\section{In His Strong Grip,}

Gretchen Wilhelm 


\section{APPENDIX I \\ Sample Selection Criterion Checklist \\ $6^{\text {th }}$ Grade Parent Survey}

Student Name:

Date:

1. What subject(s) does your child enjoy and excel in?

2. What causes your child to feel especially good about him/herself? This might include activities, talents, acquired skills, or specific ways of communicating that your child responds to especially well.

3. Are there areas of your child's character that you have specific concerns about? How would you like to see him or her improve?

4. Describe an incident that illustrates the way your child learns. 
5. What are your child's interests outside of school?

6. What is one of your child's favorite books and/or favorite movie?

7. Is there any other information you would like to share about your child?

\section{Thank you so much for your input parents! I look forward to reading your survey!}




\section{BIBLIOGRAPHY}

Alexander, H. A. (2003). Moral education and liberal democracy: Spirituality, community, and character in an open society. Educational Theory, 53(4), 367-387.

Algera, H. F., \& Sink, C. A. (2002). Another look at character education in Christian schools. Journal of Research on Christian Education, 11(2), 161-181.

Anderson, D. R. (2000). Character education: Who is responsible? Journal of Instructional Psychology, 27(3), 139-142.

Archambault, R. D. (Ed.). (1964). John Dewey on education: Selected writings. New York, NY: Random House.

Basham, Patrick (2001). Home Schooling: From the extreme to the mainstream. Vancouver, BC: The Fraser Institute.

Beehner, J. F. (1999). True wealth: How 100 Americans learned character, moral, and spiritual truths. Jacksonville, FL: By the Book Publishing.

Bennett, William J. (1993). The book of virtues: A treasury of great moral stories. New York: Simon and Schuster.

Bennett, William J. (1994). The de-valuing of America: The fight for our culture and our children. Colorado Springs, CO: Focus on the Family Publishing.

Benning, V. (1997, January 20). Homeschooling's mass appeal. The Washington Post. 
Benninga, Jacques S. (1988). An emerging synthesis in moral education. Phi Delta Kappan, 69(6), 415-419.

Benninga, Jacques S. (Ed.). (1991). Moral, character and civic education in the elementary school. New York: Teachers College Press.

Bowles, S. (2001, April 17). Educators try to establish anti-bully policies. USA Today, A4.

Brooks, D. (2001). Readings and activities for character education: A resource guide for teachers and students. Peterborough, NH: Cobblestone Publishing Company.

Brooks, David \& Goble, Frank G. (1997). The case for character education: The role of the school in teaching values and virtues. VHS. Northridge, CA: Studio 4 Productions.

Bulach, C. R. (2002, November/December). Implementing a character education curriculum and assessing its impact on student behavior. The Clearing House, 76(2) 79-83.

Bull, N. J. (1969). Moral education. Beverly Hills, CA: Sage Publications.

Chazan, B. (1985). Contemporary approaches to moral education. New York, NY: Teachers College Press.

Cloud, J. \& Morse J. (2001, August 27). Is home schooling good for America? Time Magazine. Cover Story, 124-131.

Coles, R. (1986). The moral life of children. Boston: Houghton Mifflin. 
Coons, J. E. (1992). Schools and simple justice. First Things, 22(1), 15-22.

Cornett, J. W., \& Chant, R. H. (2000). Educating youth for decency and virtue: lawrelated education and its implication for character educators. Journal of Humanistic Counseling, Education \& Development, 39(1), 26-32.

Council for American Private Education (2004, October). Private school facts. Germantown, MD.

Crawford, P. D. (2001). Educating for moral ability: Reflections on moral development based on Vygotsky's theory of concept formation. Journal of Moral Education Ltd., $30(2)$.

Damon, W. (1996). Greater Expectations: Overcoming the Culture of indulgence in America's Homes and Schools. New York: Free Press.

Damon, W. (2002). Bringing in a new era in character education. Stanford, CA: Hoover Institution Press.

Davis, M. (Nov. 2003). What's wrong with character education? American Journal of Education, 110, 32-57.

Dawidowicz, P. M. (Sept. 2003). Teaching morality in schools in Utah's religion-based society. Journal of Moral Education, 32(3), 275-289.

DeRoche, E. F. (2000). Creating a framework for character education. Principal, 79(3), 32.

Dobson, J. (1992). The new dare to discipline. Wheaton, IL: Tyndale House Publishers. 
Dobson, L. (2003). What the rest of us can learn from home schooling. New York, NY: Three Rivers Press.

Durkheim, E. (1961). Moral education: A study in the theory and application of the sociology of education. New York, NY: MacMillan Publishing Co.

Dykstra, C. (1981). Vision and character: A Christian educator's alternative to Kohlberg. New York, NY: Paulist Press.

Educational Policies Commission. (1951). Moral and spiritual values in the public schools. Washington D.C.: National Education Association of the United States.

Edwards, Carolyn P. (1986). Promoting social and moral development in young children. New York, NY: Teachers College Press.

Elias, J. L. (1989). Moral education: secular and religious. Malabar, FL: Robert E. Krieger Publishing Company.

Ferguson, A. (1999, May 24). Character goes back to school. Time Magazine, 68-69.

Gatto, J. T. (2001). A different kind of teacher: Solving the crisis of American schooling. Berkeley, CA: Berkeley Hills Books.

Gauld, L., \& Gauld, M. (2002). The biggest job we'll ever have. New York, NY: Scribner Press.

Gilness, J. (2003). How to integrate character education into the curriculum. Phi Delta Kappan, 85(3), 243-245. 
Glanzer, P. L. (2003). Did the moral education establishment kill character? An autopsy of the death of character. Journal of Moral Education, 32(3), 291-306.

Gordon, Edward E. \& Elaine H. G. (1990). Centuries of Tutoring: A history of alternative education in American and Western Europe. New York: University Press.

Gow, K. M. (1985). Yes, Virginia, Tthere is right and wrong: What values are our children being taught in the public schools? Wheaton, IL: Tyndale House Publishing.

Guinness, Os. (Ed.). (1999). Character counts: leadership qualities in Washington, Wilberforce, Lincoln, and Solzhenitsyn. Grand Rapids, MI: Baker Books.

Gutterson, David (1993). Family matters: Why home schooling makes sense. New York: Harvest Books.

Heslep, R. D. (1995). Moral education for Americans. Westport, CT: Praeger Publishers.

Himmelfarb, G. (1995). The demoralization of society: From Victorian virtues to modern values. New York: Alfred A. Knopf Publishing Company.

Huffman, H. (1994). Developing a character education program. Alexandria, VA: The Character Education Partnership.

Hunt, T. C., \& Maxson, M. M. (1981). Religion and morality in American schooling. Washington D. C.: University Press of America. 
Hunter, J. D. (2000). The death of character: moral education in an age without good or evil. New York, NY: Basic Book Publishers.

Ingersoll, J. (1990). Train up a child. Master’s thesis. George Washington University.

Jackson, Philip W., Bosnom, Robert E, \& Hansen, David T. (1993). The moral life of schools. San Francisco: Jossey Bass.

Jensen, L. C., \& Knight, R. S. (1981). Moral education: Historical perspectives. London, England: Univerisity Press of America.

Josephson Insitute of Ethics. (1998, October). 1998 report card on the ethics of American youth. Available: www.Josephsoninstitute.org/98survey/.htm:

Josephson Institute of Ethics. (2001, April). The ethics of American youth, violence and substance abuse: Data and commentary. Available: www.josephsoninstitute.org/ survey2000/violence2000-commentary.htm:

Kagan, S. (2001, October). Teaching for character and community. Educational Leadership, 50-55.

Kantrowitz, Barbara and Pat W. (1998, October 5). Home schooling - learning at home: Does it pass the test? Newsweek. Cover Story.

Kay, Barbara. (2001, August 15). School's out forever. The National Post.

Kilpatrick, William K. (1992). Why Johnny can't tell right from wrong. New York, NY: Simon \& Schuster. 
Kilpatrick, William K., Wolfe, Gregory \& Suzanne M. (1994). Books that build character: A guide to teaching your child moral values through stories. New York: Simon and Schuster.

Kirschenbaum, H. (1977). In support of values clarification. Social Education, 41(1), 398-402.

Kirschenbaum, Howard (1995). 100 ways to enhance values and morality in schools and youth settings. Needharn Heights, MA: Simon and Schuster Plublishers.

Kohlberg, Lawrence (1981). Essays on moral development: The philosophy of moral development. (Vol. I, pp. 231-243). San Francisco, CA: Harper and Row.

Kohlberg, Lawrence (1984). Essays on moral development: The psychology of moral development. (Vol. II). San Francisco: Harper and Row.

Kozol, J. (2001). Choosing excellence. Lanham, MD: The Scarecrow Press, Inc.

Leming, James S. (1993). Character education: Lessons from the past, models for the future. Camden, ME: The Institute for Global Ethics Publications.

Leming, James. S. (2000). Tell me a story: an evaluation of a literature-based character education programme. Journal of Moral Education, 29(4), 413-427.

Leung, Rebecca (2000, September 15). Teach your children well. ABC NEWS.

Lewis, C. S. (1947). The abolition of man. New York, NY: Simon \& Schuster Press. 
Lickona, T. (Ed.). (1976). Moral development and behavior: Theory, research and social issues. New York, NY: Halt, Rinehart and Winston Publishers.

Lickona, T. (1991). Educating for character: How our schools can teach respect and responsibility. New York: Bantam Publishers.

Lickona, T. (1993). The return of character. Educational Leadership, 51(3), 6-11.

Lickona, T., Schaps, E., \& Lewis, C. (1996). Eleven principles of effective character education. Journal of Moral Education, 25(1), 93-100.

Lickona, Thomas, Eric Schaps, \& Catherine Lewis. (1998, November/December) Eleven Principles of Effective Character Education. Scholastic Early Childhood Today, 13 (3), 53-36.

Lickona, T. (2004). Character matters: How to help our children develop good judgment, integrity, and other essential virtues. New York, NY: Simon \& Schuster.

Liermann, D. (1999). Character education and Christian education: Is it really happening? Paper presented at the Conference on the Social and Moral Fabric of School Life. Edmonds, WA: Sage Publications.

Lines, Patricia M. (2000). When homeschoolers go to school: A partnership between families and schools. Peabody Journal of Education. Vol. 75, No. 1-2, 159-86.

Livni, Ephrat. (2000, August 23). Keeping the Faith. ABC NEWS. 
Loria, Olivia. (2002). On the front lines of home education nationally and internationally. Retrieved June 27, 2005, from http://www.education revolution.org/homedbyollor.htlm.

Martinson, D. L. (2003, September/October). High school students and character education: it all started at Wendy's. The Clearing House, 77(1) 14-17.

Matera, D. (2001). A cry for character: how a group of students cleaned up their rowdy school and spawned a wildfire antidote to the columbine effect. Paramus, NJ: Prentice Hall Press.

Maushard, M. (1996, April 25). Parent discontent fuels home schooling. Baltimore Sun, pp. 1A-2A.

May, P. R. (1971). Moral education in school. London, England: Methuen Educational LTD.

McClellan, B. E. (1992). Schools and the shaping of character: moral education in America, 1607-present. Bloomington, IN: ERIC Clearing House Publishers.

McClellan, B. E. (1999). Moral education in America: Schools and the shaping of character from colonial times to the present. New York, NY: Bantam Publishers.

McDowell, J., \& Hostetler, B. (1998). The new tolerance: How a cultural movement threatens to destroy you, your faith, and your children. Wheaton, IL: Tyndale House Publishers. 
McDowell, Susan A. \& Brian D. Ray (2000). (Eds.). The home education movement in context, practice, and theory. Peabody Journal of Education (June).

Milson, A. J., \& Mehlig, L. M. (2002, September/October). Elementary school teacher's sense of efficacy for character education. The Journal of Educational Research, 96(1), 47-53.

Molnar, A., Ed. (1997). The construction of children's character. Chicago, IL: University of Chicago Press.

Murphy, M. (1998). Character education in America’s blue ribbon schools. Lancaster, PA: Technomic Publishers.

Nash, R. J. (1997). Answering the "virtuecrats": A moral conversation on character education. New York, NY: Teachers College Press.

National Association of Secondary School Principals. (1996). Breaking point: Changing an American institution. No. 12. Richmond, Virginia: NASSP.

Noddings, N. (2002). Educating moral people: A caring alternative to character education. New York, NY: Teacher College Press.

Nord, W., \& Haynes, C. (1998). Taking religion seriously across the curriculum. Alexandria, VA: Association for Supervision, Curriculum, and Development.

O'Sullivan, S. (2004, April), Books to live by: using children's literature for character education. The Reading Teacher, 57(7) 640-645.

Piaget, J. (1965). The moral judgment of the child. New York: The Free Press. 
Purpel, D., \& Ryan, K. (1976). Moral education. Berkeley, CA: McCutchan Publishing Corporation.

Raths, L., Harmin, M., \& Simon, S. B. (1966). Values and teaching. Columbus, OH: Merrill Publishing House.

Ray, Brian D. (1999). Home schooling on the threshold: A survey of research at the dawn of the new millennium. No. 1). Salen, OR: National Home Education Research Institute.

Ray, Brian D. (2000). Homeschooling: The ameliorator of negative influences on learning? Peabody Journal of Education 75(1), 71-106.

Ray, Brian D. (2001). Home education in Ohio: Family characteristics, academic achievement, social and civic activities, and college admissions officers’ thoughts. Available from the National Home Education Research Institute, P.O. Box 13939, Salem, OR 97309.

Ray, Brian D. (2001). The modern homeschooling movement. Catholic Education: A Journal of Inquiry and Practice. 4(3), 405-421.

Ray, Brian D. (2002). A quick reference worldwide guide to homeschooling: Facts and stats on the benefits of home education, 2002-2003. Nashville, TN: Broadman \& Holman Publishers.

Ray, Brian D. (2004). Home educated and now adults: Their community and civic involvement, views about homeschooling, and other traits. Kearney, NE: Morris Publishing. 
Ray, Brian D. \& Lloyd William A. (2000). Homeschooling in 2000 and beyond:

Cultural, social. And economic factors in the light of educational sovereignty. A paper presented at the annual meeting of Worlddidac, March 30, 2000, Zurich, Switzerland.

Reimer, Joseph, Paolitto, D.R. and Hersh, R.H. (1983). Promoting moral growth: From Piaget to Kohlberg. New York: Longman Publishing.

Revell, L. (2002). Children's responses to character education. Educational Studies, 28(4), 421-431.

Rhodes, Tom (2000, September 10). U.S. Parents switch to home schooling. The Times.

Rudner, Lawrence M. (1999, March 23). Scholastic achievement and demographic characteristics of home school students in 1998. Educational Policy Analysis Archives. 7(8). On the internet at: http://www.epaa.asu.edu/epaa/v7n8/.

Rusnak, T. (1998). An integrated approach to character education. Thousand Oaks, CA: Corwim Press, Inc.

Ray, Brian D. (2004). Home educated and now adults: Their community and civic involvement, views about homeschooling, and other traits. Kearney, NE: Morris Publishing.

Ryan, Kevin and Bohlin, Karen. (1999). Building character in schools: Practical ways to bring moral instruction to life. . San Francisco, CA: Jossey-Bass Publisher. 
Ryan, K. (1996). Character education in the United States: A status report. Journal for a Just and Caring Education, 2(1), 75-84.

Ryan, K. (1986). The new moral education. PhiDelta Kappan, 68, 228-233.

Schaps, E. (2002, June 19). Community in school: Central to character formation and more. White House Conference (6) 2-7.

Schaps, E. (2003, March). Creating a school community. Educational Leadership, 60(6) 31-33.

Schindler, Claude E. (1987). Sowing for excellence: Educating God's way. Whittier, CA: Association of Christian Schools International Publishing.

Schultz, L. H., Barr, D. J., \& Selman, R. L. (2001). The value of a developmental approach to evaluating character development programmes: an outcome study of facing history and ourselves. Journal of Moral Education, 30(1), 3-27.

Sizer, N. F., \& Sizer, T. R. (Eds.). (1970). Moral education: Five lectures. Cambridge, MA: Harvard University Press.

Snyder, H. N., \& Sickmund, M. (1999). Juvenille offenders and victims: National report. Washington, D.C.: Office of Juvenile Justice and Delinquency Prevention, U.S. Dept. of Justice.

Specklow, S. (1994). Live and Learn: Fed up with schools, more parents turn to teaching at home. The Wall Street Journal (May 10). 
Tappan, M. (1998). Moral education in the zone of proximal development. Journal of Moral Education, 27(1), 141-160.

Van Galen, Jane A. (1991). Ideologues and Pedagogues: Parents who teach their children at home. In Jane Van Galen and Mary Anne Pittman. (Eds.). Home Schooling: Political, Historical, and Pedagogical Perspectives. Norwood, NJ: Ablex Publishers.

Vessels, G., \& Boyd, S. M. (1996). Public and constitutional support for character education. NASSP Bulletin, 80(579), 55-62.

Vincent, Philip F. (1996). Promising Practices in Character Education: Nine Success Stories From Around the Country. Chapel Hill, NC: Character Development Group.

Wagner, T. (2002). Making the grade: Reinventing America's schools. New York, NY: Routledge Falmer Inc.

Weber, C. (1998). Pre-service preparation for teaching character and citizenship: an integrated approach. Action in Teacher Education, 20(4), 85-95. From EBSCO database.

Weissbourd, R. (2003, March). Moral teachers, moral students. Educational Leadership, 60(6) 6-11.

Wells, D. F. (1998). Losing our virtue. Grand Rapids, MI: William B. Eerdmans Publishing Company. 
Williams, D. D., Yanchar, S. C., \& Jensen, L. C. (2003). Character education in a public high school: A multi-year inquiry into unified studies. Journal of Moral Education, 32(1), 3-33.

Wilson, James Q. (1993). The moral sense. New York: Free Press.

Wiley, Lori S. (1997). The comprehensive character-building classroom: A handbook for teachers. Manchester, NH: The Character Development Foundation.

Wynne, E. A., \& Benninga, Jacques S. (Eds.). (1991). Moral character and civic education in the elementary schools. New York, NY: Teachers College Press.

Wynne, E. A., \& Ryan, K. (1993). Reclaiming our schools: A handbook on teaching character, academics, and discipline. New York, NY: Macmillian. 


\section{VITA}

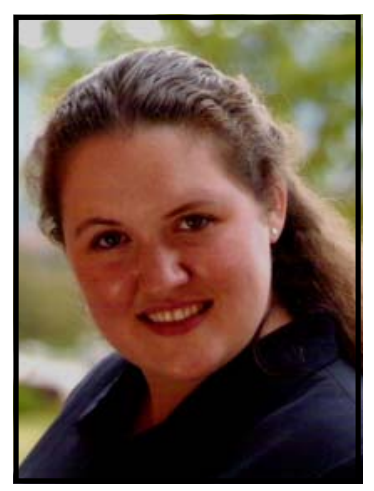

Gretchen Marie Wilhelm was born in Fairview Park, Ohio on June 11, 1981 and grew up in Rocky River on the outskirts of Cleveland. She is the eldest children of her parents, Chuck and Sue Marie Wilhelm, and has three brothers and two sisters who are twins. All the Wilhelm children were, and continue to be, home educated from kindergarten through high school. Gretchen currently resides with her family and younger siblings at the Wilhelm home in Columbia Station, Ohio.

Miss Wilhelm was raised in a loving Christian home and accepted Jesus as her personal Savior at the young age of four. As a child, Gretchen loved reading and pursued musical training which eventually led her to Baldwin-Wallace Conservatory of Music in Berea, Ohio. Having attended college her junior and senior years of high school as a Post Secondary Options Honor Student, Gretchen was able to finish her Bachelor's degree in the two years following her graduation from high school, May 2000.

After receiving a Bachelor's of Music in Music History and Literature from Baldwin-Wallace Conservatory of Music in May 2002, Gretchen continued to teach in her private music studio which she founded in May 1999 along with numerous other home-based business ventures. Gretchen’s love for teaching music led her to accept a position after graduating from college as music director at Greater Cleveland Christian School and H.E.A.R.T.S. Educational Institute in September 2002.

After a year of teaching $7^{\text {th }}-12^{\text {th }}$ grade, the Lord led her to attend the Focus on the Family Leadership Institute in Colorado Springs, CO. This internship was the highlight of her continuing education. Upon her return to the Cleveland area, Gretchen was hired as the $6^{\text {th }}$ grade teacher at Christian Community School where she currently serves as a second year teacher, mentor, and visionary.

Gretchen eagerly chose to attend Cedarville University’s Graduate Program in the fall of 2002 after her graduation from undergraduate studies at Baldwin-Wallace College. Gretchen found the Christian perspective and educational integrity of Cedarville University’s Graduate Program of great importance in her development as an educator. She is committed to professionalism as an educator and wishes to pursue future world travels and a part-time career as a writer. Miss Wilhelm completed her Master’s Degree in Education in May 2005. 